\title{
Hygroscopic mixing state of urban aerosol derived from size-resolved cloud condensation nuclei measurements during the MEGAPOLI campaign in Paris
}

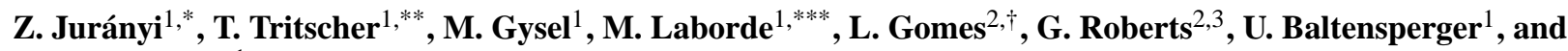 \\ E. Weingartner ${ }^{1}$ \\ ${ }^{1}$ Laboratory of Atmospheric Chemistry, Paul Scherrer Institute, 5232 Villigen PSI, Switzerland \\ ${ }^{2}$ CNRS-GAME/Météo France, 42 av. Gaspard Coriolis, 31057 Toulouse, France \\ ${ }^{3}$ Scripps Institution of Oceanography, 9300 Gilman Dr., La Jolla CA 92093, USA \\ *now at: Institute of Aerosol and Sensor Technology, University of Applied Sciences Northwestern Switzerland, \\ Klosterzelgstrasse 2, 5210 Windisch, Switzerland \\ ** now at: TSI GmbH, Particle Instruments, Neuköllner Strasse 4, 52068 Aachen, Germany \\ ${ }^{* * *}$ now at: Ecotech PtyLtd, Knoxfield, Australia and AerosolConsultingML GmbH, Ennetbaden, Switzerland \\ ${ }^{\dagger}$ deceased
}

Correspondence to: M. Gysel (martin.gysel@psi.ch)

Received: 3 December 2012 - Published in Atmos. Chem. Phys. Discuss.: 21 January 2013

Revised: 23 May 2013 - Accepted: 3 June 2013 - Published: 8 July 2013

\begin{abstract}
Ambient aerosols are a complex mixture of particles with different physical and chemical properties and consequently distinct hygroscopic behaviour. The hygroscopicity of a particle determines its water uptake at subsaturated relative humidity $(\mathrm{RH})$ and its ability to form a cloud droplet at supersaturated RH. These processes influence Earth's climate and the atmospheric lifetime of the particles.

Cloud condensation nuclei $(\mathrm{CCN})$ number size distributions (i.e. $\mathrm{CCN}$ number concentrations as a function of dry particle diameter) were measured close to Paris during the MEGAPOLI campaign in January-February 2010, covering 10 different supersaturations ( $\mathrm{SS}=0.1-1.0 \%$ ). The timeresolved hygroscopic mixing state with respect to $\mathrm{CCN}$ activation was also derived from these measurements. Simultaneously, a hygroscopicity tandem differential mobility analyser (HTDMA) was used to measure the hygroscopic growth factor (ratio of wet to dry mobility diameter) distributions at $\mathrm{RH}=90 \%$. The aerosol was highly externally mixed and its mixing state showed significant temporal variability. The average particle hygroscopicity was relatively low at subsaturation $(\mathrm{RH}=90 \%$; mean hygroscopicity parameter $\kappa=0.12$ 0.27 ) and increased with increasing dry diameter in the range $35-265 \mathrm{~nm}$. The mean $\kappa$ value, derived from the CCN mea-
\end{abstract}

surements at supersaturation, ranged from 0.08 to 0.24 at $\mathrm{SS}=1.0-0.1 \%$.

Two types of mixing-state resolved hygroscopicity closure studies were performed, comparing the water uptake ability measured below and above saturation. In the first type the $\mathrm{CCN}$ counter was connected in series with the HTDMA and and closure was achieved over the whole range of probed dry diameters, growth factors and supersaturations using the $\kappa$-parametrization for the water activity and assuming surface tension of pure water in the Köhler theory. In the second closure type we compared hygroscopicity distributions derived from parallel monodisperse $\mathrm{CCN}$ measurements and HTDMA measurements. Very good agreement was found at all supersaturations, which shows that monodisperse CCN measurements are a reliable alternative to determine the hygroscopic mixing state of ambient aerosols.

\section{Introduction}

The hygroscopicity of aerosol particles determines their ability to take up water. This water uptake plays an important role in the Earth's climate as it influences the particles' ability to scatter and absorb solar radiation (direct aerosol effect) and 
the microphysical properties of clouds (indirect aerosol effect). Aerosol particles that are able to activate and become cloud droplets at a certain supersaturation (SS) are commonly termed cloud condensation nuclei $(\mathrm{CCN})$. The critical supersaturation $\left(\mathrm{SS}_{\text {crit }}\right)$ of a particle, defined as the supersaturation at which the cloud droplet activation takes place, is determined by its dry size and chemical composition.

Ambient aerosol particles are mainly composed of inorganic ions, organic components, black carbon, and mineral dust (Zhang et al., 2007). Most of the time they are heterogeneous mixtures of particles with different chemical composition and sizes, rather than homogeneous mixtures of particles with identical chemical composition only differing in size. More specifically, we refer to an internally mixed aerosol if all particles with the same dry size have identical chemical composition, which still allows for the presence of size-dependent chemical composition. In an externally mixed aerosol, particles of equal dry size but different chemical composition are present. Internal mixture implies that all particles with equal dry size have equal hygroscopicity, whereas a distribution of different hygroscopicities can be observed for externally mixed aerosols. This mixing state of aerosols might be important for the cloud activation processes (Anttila, 2010) since it determines which particle fraction will activate to cloud droplets. Composition dependent droplet activation also influences the atmospheric lifetime of different particulate species through wet removal via in-cloud scavenging. For example, freshly emitted black carbon (BC) particles from road traffic are often non-hygroscopic and externally mixed with other components (e.g. Baltensperger et al., 2002), and therefore they are not able to act as $\mathrm{CCN}$ at atmospherically relevant $\mathrm{SS}_{\text {crit }}$ values (Hitzenberger et al., 2003; Koehler et al., 2009; Tritscher et al., 2011a). However, with time and aging these BC particles coagulate with other particles or become coated by condensation of hygroscopic material (Zhang et al., 2008) and therefore become important for CCN activation (Kuwata et al., 2009; Tritscher et al., 2011a). Such atmospheric aging processes increase the degree of internal mixture of aerosols (Swietlicki et al., 2008), thereby reducing composition specific droplet formation (Cozic et al., 2007), as the CCN activation behaviour of internally mixed aerosols is solely determined by particle size and the mean composition (Jurányi et al., 2010).

A commonly applied method to measure the mixing state of atmospheric aerosols is to use a hygroscopicity tandem differential mobility analyser (HTDMA), which measures the distribution of the growth factor (GF, ratio of wet to dry mobility diameter) at a certain relative humidity $(\mathrm{RH})$ of particles with a well-defined dry mobility diameter $(D)$. Several studies on ambient aerosol applying a HTDMA also report mixing state information (e.g. Swietlicki et al., 2008; Kammermann et al., 2010a; Liu et al., 2011; Fors et al., 2011).

It has also been shown by Su et al. (2010) that diameterresolved $\mathrm{CCN}$ activation measurements contain equivalent information on the aerosol hygroscopic mixing state (i.e. the mixing state with respect to the hygroscopic behaviour of the particles). Such monodisperse CCN measurements are often performed in both laboratory (Padro et al., 2007; Herich et al., 2009; Jurányi et al., 2009; Petters et al., 2009; Frosch et al., 2010) and ambient studies (Gunthe et al., 2009, 2011; Rose et al., 2010). However, most studies only report the average hygroscopicity of the aerosol population, while only a few studies additionally report mixing state information such as the width of the hygroscopicity distribution (Gunthe et al., 2009; Rose et al., 2010).

The hygroscopic growth at subsaturation and the CCN activity of particles are linked via the Köhler theory. Hygroscopicity-CCN closure studies compare the water uptake on aerosols below saturation to $\mathrm{CCN}$ properties using different parametrizations of the Köhler theory (Kammermann et al., 2010b, and references therein). Most of the existing ambient studies compare predicted and measured CCN number concentrations $\left(N_{\mathrm{CCN}}\right)$ and most of the time they successfully predict the CCN number concentration within $\pm 30 \%$ (e.g. Rissler et al., 2004; Vestin et al., 2007; Kammermann et al., 2010b; Fors et al., 2011); however in some studies substantially higher discrepancies were observed (e.g. Ervens et al., 2007; Gasparini et al., 2006; Irwin et al., 2011). Some of these studies take the aerosol mixing state into account (Rissler et al., 2004; Gasparini et al., 2006; Kammermann et al., 2010b; Fors et al., 2011), while some others assume an internally mixed aerosol and with that neglect the mixing state (Vestin et al., 2007; Snider et al., 2003). Composition-CCN closure studies, where the $\mathrm{CCN}$ properties or number concentrations are predicted using information on the chemical composition, mostly assume an internally mixed aerosol, since information on only bulk and no single particle chemical composition is available (e.g. Ervens et al., 2007; Cubison et al., 2008; Lance et al., 2009; Jurányi et al., 2010). Some studies report that the way of treatment of the mixing state does not significantly influence the predicted $N_{\text {CCN }}$ (Rissler et al., 2004; Ervens et al., 2010; Kammermann et al., 2010b). However, composition-specific wet removal efficiency via droplet nucleation will depend on mixing state of the aerosol. We are only aware of a single study (Mochida et al., 2006) that has probed the consistency of the mixingstate resolved hygroscopicity measurements at sub- and supersaturated RH with Köhler theory.

In this paper we report the hygroscopic mixing state of the urban aerosol in Paris where freshly emitted, externally mixed aerosols are often present, and we additionally address the following scientific questions: Is it possible to derive the hygroscopic mixing state from $\mathrm{CCN}$ measurements? Can simple parametrizations of the Köhler equation be used to link the hygroscopic growth of particles below water vapour saturation with their $\mathrm{CCN}$ activity at supersaturation? Is it possible to successfully achieve a mixing-state resolved hygroscopicity- $\mathrm{CCN}$ closure at a site close to Paris, where 
a fresh and often externally mixed aerosol with high temporal variability is present?

\section{Experimental}

\subsection{Measurement site}

The measurements were performed in winter 2010 within the framework of the MEGAPOLI European project (Megacities: Emissions, urban, regional and Global Atmospheric POLlution and climate effects, and Integrated tools for assessment and mitigation; Baklanov et al., 2010; Beekmann et al., 2013) campaign at the SIRTA site (Site Instrumental de Recherche par Télédétection Atmosphérique) in Paris. SIRTA is a peri-urban site located on the campus of the Ecole Polytechnique $\sim 20 \mathrm{~km}$ southwest of Paris city centre. The site is directly surrounded by agricultural fields, forests, industrial areas and households; polluted air from the Paris metropolitan area is often transported to the site as well. More information on the measurement site can be found elsewhere (Haeffelin et al., 2005).

\subsection{Measurement setup}

\subsubsection{Scanning diameter $\mathrm{CCN}$ counter $(\mathrm{CCNC})$}

The scanning diameter CCNC measurement setup was based on a custom-built scanning mobility particle sizer system (SMPS; Fig. 1a), which was successfully validated during an SMPS intercomparison workshop (Wiedensohler et al., 2012). This measurement setup was used between 3 February 2010 and 13 February 2010. The quasi-monodisperse aerosol particles leaving the DMA (differential mobility analyser) were counted by a CPC (condensation particle counter, TSI 3022) and also fed to a continuous-flow streamwise thermalgradient CCN counter (CCNC, Droplet Measurement Technologies, model CCN-100; Roberts and Nenes, 2005). This allows simultaneous measurement of both the dry particle number size distribution $(n(D))$ and the dry CCN number size distribution $\left(n_{\mathrm{CCN}}(D, \mathrm{SS})\right)$ at the SS applied in the CCNC. This measurement setup is similar to the scanning mobility CCN analysis introduced by Moore et al. (2010).

The aerosol was dried to $\mathrm{RH}<15 \%$ with a diffusion drier before entering the DMA, which was operated in scanning voltage mode with a $0.8 \mathrm{Lmin}^{-1}\left(0.5 \mathrm{~L} \mathrm{~min}^{-1} \mathrm{CCN}\right.$ counter and $0.3 \mathrm{~L} \mathrm{~min}^{-1} \mathrm{CPC}$ sample flow rates) to $6 \mathrm{~L} \mathrm{~min}^{-1}$ sample-to-sheath flow ratio. The diameter range from 10 $413 \mathrm{~nm}$ (mobility diameter of singly charged particles) was scanned by the DMA over a duration of $300 \mathrm{~s}$. The SS in the $\mathrm{CCNC}$ was held constant during two diameter scans. However, sometimes only one out of the two diameters scans provided valid data whenever the SS setpoint changed during a diameter scan due to imperfect time synchronization of DMA and CCNC. Measurements were done at 10 different

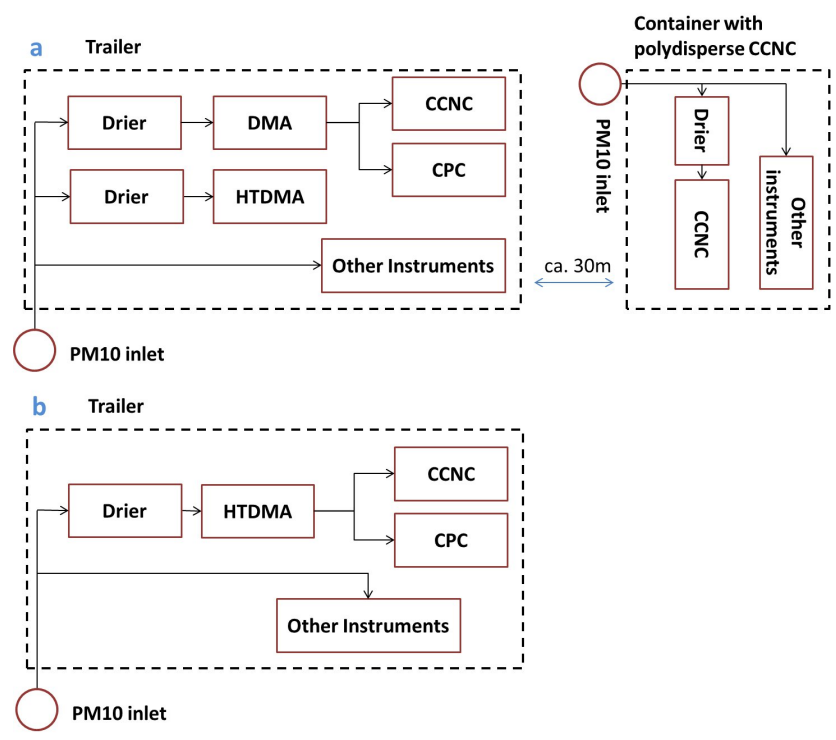

Fig. 1. Measurement setup of the scanning diameter CCNC, polydisperse CCNC (a) and of the coupled HTDMA-CCNC (b).

SS (SS $=0.1-1 \%$ ) such that during the 10 days' measurement period $\sim 100$ valid $n_{\mathrm{CCN}}$ scans per SS were acquired.

Close to the trailer, where the diameter scanning CCNC and the HTDMA were placed, a container was situated in which another identical CCNC instrument (see Fig. 1a) simultaneously measured the polydisperse $\mathrm{CCN}$ number concentration $\left(N_{\mathrm{CCN}}(\mathrm{SS})\right)$ at 5 different $\mathrm{SS}$ values $(\mathrm{SS}=0.15$ $0.46 \%)$.

Particles having lower $\mathrm{SS}_{\text {crit }}$ than the SS applied in the CCNC's activation column grow to supermicrometer sized droplets and are counted as $\mathrm{CCN}$ by the optical particle sizer downstream of the activation column. The SS in the DMT CCNC is determined by the applied temperature gradient along the activation column's wetted wall and the total flow rate. The temperature gradient to SS relationship for a total flow rate of $0.5 \mathrm{~L} \mathrm{~min}^{-1}$ (1 to 10 sample-to-sheath flow ratio in the $\mathrm{CCNC}$ ) was determined during calibration measurements using nebulized, dried and size-selected pure ammonium sulphate particles. At a certain temperature gradient the critical dry diameter, $D_{\text {crit }}$, where $50 \%$ of the singly charged ammonium sulphate particles are activated, was determined from the inverted activated fraction scans using the same measurement setup as described above (see Sect. 3 for details on the inversion). Theoretical $\mathrm{SS}_{\text {crit }}$ values corresponding to the measured $D_{\text {crit }}$ values for ammonium sulphate were obtained from the ADDEM model (Topping et al., 2005). The range of the applied temperature gradients during calibrations was chosen to cover the range of SS applied during the ambient measurements. 


\subsubsection{Hygroscopicity tandem differential mobility analyser}

Parallel to the diameter scanning CCN counter setup, the GF probability density function (GF-PDF) at $\mathrm{RH}=90 \%$ was measured at 6 different dry diameters $(D=35,50,75,110$, 165 and $265 \mathrm{~nm}$ ) by a custom-built HTDMA. The GF-PDF of an aerosol sample describes the likelihood that a particle with a defined dry size exhibits a certain GF at the specified RH. A detailed description of the HTDMA employed in this study can be found elsewhere (Tritscher et al., 2011b). First, the aerosol is dried to $\mathrm{RH}<15 \%$ before entering a DMA, which selects a quasi monodisperse aerosol with well-defined dry diameter. The size-selected particles are then humidified to $90 \% \mathrm{RH}$ and the number size distribution of the humidified particles is determined by a second DMA and a CPC (TSI 3022). The accuracy of the HTDMA was verified using pure ammonium sulphate aerosol as described in Gysel et al. (2002).

\subsubsection{Coupled HTDMA-CCNC setup}

For the time period 16-29 January 2010 the experimental setup was modified such that the CCNC and a parallel CPC were connected to the outlet of the HTDMA (Fig. 1b). This means that the aerosol was first dry-size selected, then hygroscopicity (GF) selected, before entering the CCNC and the CPC. The SS applied in the CCNC was very slowly stepped (21 setpoints of $40 \mathrm{~min}$ duration each; covering the SS range $0.1-1.7 \%$ ), such that normally a constant SS was applied while scanning through GFs with the second DMA of the HTDMA system at each dry diameter ( $300 \mathrm{~s}$ per scan covering the GF range $0.5-2.5$ ). This approach was chosen to determine the $\mathrm{SS}_{\text {crit }}(D, \mathrm{GF})$ for particles with a well-defined GF and dry size.

\section{Theory and data analysis}

\section{1 $\kappa$-Köhler theory}

In order to be able to link the hygroscopicity measurements below and above water vapour saturation, i.e. equilibrium growth factor with critical supersaturation, the solution concentration dependence of the water activity in the Köhler equation (Köhler, 1936; McFiggans et al., 2006) was parameterised using the single-parameter $\kappa$ parametrization (Petters and Kreidenweis, 2007). The equilibrium saturation ratio over a solution droplet then becomes

$S=\left(1+\kappa \frac{D^{3}}{D_{\text {drop }}^{3}-D^{3}}\right)^{-1} \exp \left(\frac{4 \sigma M_{\mathrm{w}}}{R T D_{\text {drop }} \rho_{\mathrm{w}}}\right)$

where $D$ and $D_{\text {drop }}$ are the dry particle and solution droplet diameter, respectively, $\sigma$ is the surface tension of the solution, $M_{\mathrm{w}}$ is the molar mass of water, $R$ is the universal gas constant, $\rho_{\mathrm{w}}$ is the density of water, and $T$ is the absolute temperature. For atmospheric aerosols, the values of the semi-empirical $\kappa$-parameter extend from 0 (non-hygroscopic but wettable) to $\sim 1.3$ (most hygroscopic salts). The surface tension of the solution droplet is also a key parameter in the Köhler equation. We used the surface tension of pure water at the appropriate temperature (HTDMA: temperature in the second DMA; CCNC: temperature at the top of the CCNC's wetted column), which is a common assumption used at high $\mathrm{RH}$ or at the point of activation.

\subsection{Data analysis}

At a given supersaturation and dry diameter the activated fraction $\operatorname{AF}(D, \mathrm{SS})$ of the particles is defined as the ratio between $n_{\mathrm{CCN}}(D, \mathrm{SS})$ and $n(D)$, and represents the fraction of particles at this dry diameter that have a critical supersaturation equal to or below SS. In practice, $\operatorname{AF}(D, \mathrm{SS})$ is measured in two different ways: either the dry diameter is held at a constant value while the SS is varied in the CCNC (S-scan), or alternatively, the SS is held constant in the CCNC and the selected $D$ is varied in the DMA (D-scan). In this study we performed D-scans at 10 different SS (SS $=0.1-1 \%)$.

Both the raw data (i.e. particle concentration as function of selected mobility diameter) of the particle and $\mathrm{CCN}$ number size distribution measurements have to be inverted in order to account for the size-dependent charging probability, presence of multiple charged particles and the DMA's transfer probability. Diffusion and other losses are neglected in our calculations. We used the inversion scheme from Petters et al. (2009) for the size distribution measurements, which works for both particle and CCN number size distributions without any prior knowledge about either the chemical composition or the mixing state of the particles.

The covered diameter range was split into a fixed number of size bins and we define the corresponding values of the particle and $\mathrm{CCN}$ raw (measured) number size distributions in bin number $i$ as

$c_{i}:=c\left(D_{i}\right)$

$c_{\mathrm{CCN} i}(\mathrm{SS}):=c_{\mathrm{CCN}}\left(D_{i}, \mathrm{SS}\right)$.

Likewise, the values of the inverted (true) size distributions are defined as

$n_{i}:=n\left(D_{i}\right)$

$n_{\mathrm{CCN} i}(\mathrm{SS}):=n_{\mathrm{CCN}}\left(D_{i}, \mathrm{SS}\right)$,

and the activated fraction can be expressed as

$\mathrm{AF}_{i}(\mathrm{SS})=n_{\mathrm{CCN} i}(\mathrm{SS}) / n_{i}$.

For the discrete diameter boundaries, a logarithmic grid was chosen with 16 bins per decade resolution. According to the 
inversion, the raw and inverted number size distributions are connected through matrix $\mathbf{A}$. The element $\mathbf{A}_{i j}$ of the $\mathbf{A}$ matrix is the response function of the DMA, which contains the probability of a particle with mobility diameter $D_{j}$ to pass the neutralizer-DMA setup if the DMA is set to the nominal mobility diameter $D_{i}$. A accounts for the DMA's transfer probability and the particles' charging probability. Therefore, the true particle and CCN number size distributions in the $i$ th diameter bin are

$n_{i}=\sum_{j} \mathbf{A}_{i j}^{-1} c_{j}$

$n_{\mathrm{CCN} i}(\mathrm{SS})=\sum_{j} \mathbf{A}_{i j}^{-1} c_{\mathrm{CCN} j}(\mathrm{SS})$,

and with this the activated fraction becomes

$\mathrm{AF}_{i}(\mathrm{SS})=\frac{\sum_{j} \mathbf{A}_{i j}^{-1} c_{\mathrm{CCN} j}(\mathrm{SS})}{\sum_{j} \mathbf{A}_{i j}^{-1} c_{j}}$.

To be able to calculate the true concentrations from the raw ones, the inverse of the $\mathbf{A}$ matrix $\left(\mathbf{A}^{-1}\right)$ has to be used. The DMA transfer function was assumed to be ideal (Knutson and Whitby, 1975), the charge equilibrium was calculated according to the Wiedensohler parametrization (Wiedensohler, 1988) with corrected coefficients (Baron and Willeke, 2001), and up to maximally 3 elementary charges per particles were considered. More details on the inversion matrix are provided in Petters et al. (2009).

Figure 2 shows the process of the inversion through an example D-scan performed at $\mathrm{SS}=0.1 \%$. Figure 2a contains the measured raw $(c(D)$, dashed brown line) and inverted $(n(D)$, dashed grey line) particle number size distributions, and Fig. $2 \mathrm{~b}$ contains the same for the $\mathrm{CCN}\left(c_{\mathrm{CCN}}(D, \mathrm{SS})\right.$ and $\left.n_{\mathrm{CCN}}(D, \mathrm{SS})\right)$. The contributions of the singly, doubly and triply charged particles to the measured raw concentrations are illustrated with the yellow, orange and red shaded areas, respectively. The shape of the grey dashed lines (the inverted concentrations) does not agree with the shape of the contribution of the singly charged particles to the raw measurement (yellow shaded areas) because the inversion not only corrects for the effect of the multiply charged particles but also accounts for the diameter dependent DMA transfer and charging probability.

The example shown in Fig. 2b illustrates that the multiply charged particles dominate the raw $\mathrm{CCN}$ signal below the activation cut-off diameter of the singly charged particles (at $\sim 120 \mathrm{~nm}$ in this specific example). Without the correction for the multiply charged particles, this would falsely be interpreted as already activated particles at that diameter. Correction of the multiply charged particles is likewise important for the resulting activated fraction, which can be seen in Fig. 2c where raw (brown dashed line) and inverted (grey dashed line) $\operatorname{AF}(D, \mathrm{SS})$ are shown.

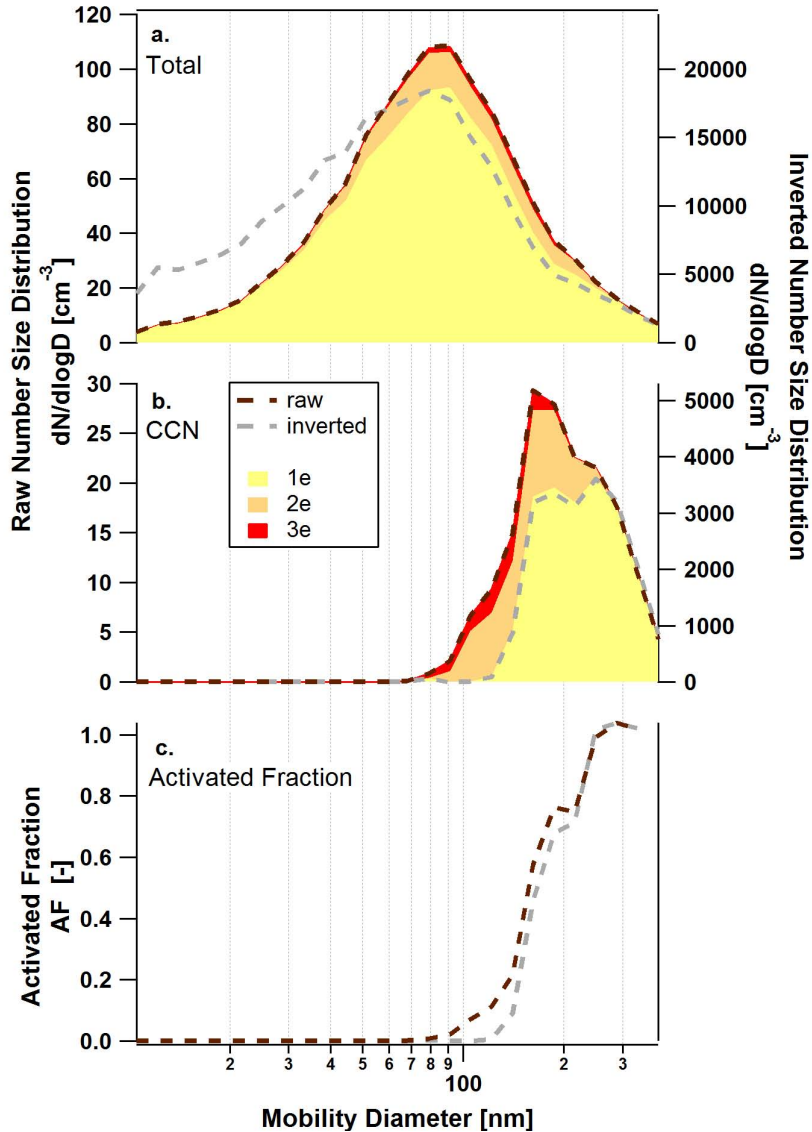

Fig. 2. Example of the particle and $\mathrm{CCN}$ (at $\mathrm{SS}=0.1 \%$ ) number size distribution measurements. Panel (a) shows measured raw particle concentration $(c(D)$, brown dashed line) and the corresponding calculated contributions from the singly (yellow shaded area), doubly (orange shaded area) and triply (red shaded area) charged particles. The grey dashed line shows the inverted number size distribution $(n(D))$. Panel (b) is same as panel (a) but for raw and inverted $\mathrm{CCN}$ number size distributions $\left(c_{\mathrm{CCN}}(D, \mathrm{SS})\right.$ and $n_{\mathrm{CCN}}(D, \mathrm{SS})$, respectively). The difference between the contributions from the singly charged particles to the raw measurement and the inverted number size distribution originates from the diameter dependent DMA transfer probability and the charging probability. Panel (c) shows the calculated raw (brown dashed line) and inverted (grey dashed line) activated fractions.

The HTDMA raw data were inverted using the TDMAinv algorithm by Gysel et al. (2009). This inversion method uses the full TDMA kernel function and assumes a piecewise linear GF-PDF. Only data measured within the range $88 \%<\mathrm{RH}<92 \%$ were considered to be valid and were recalculated to $\mathrm{RH}=90 \%$. 


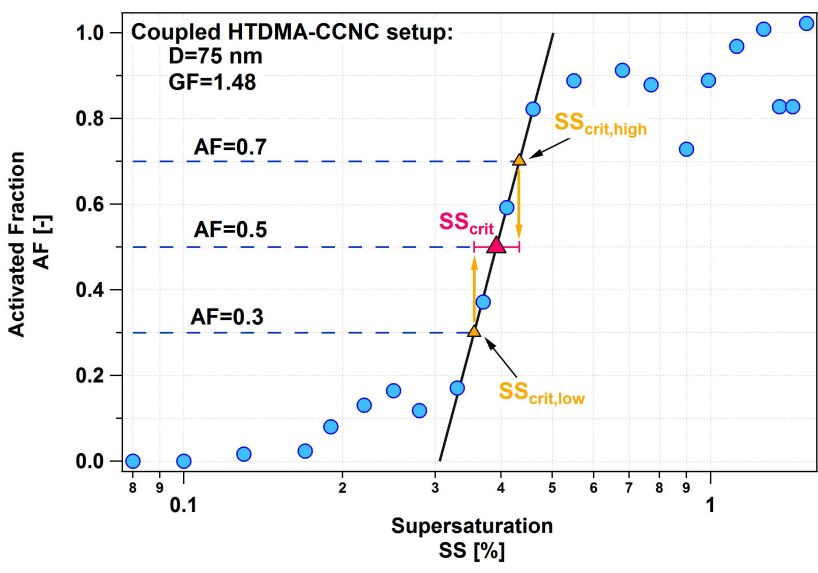

Fig. 3. Illustration of the approach to determine $\operatorname{SS}_{\text {crit }}(D, \mathrm{GF})$ from the activation curves measured with the coupled HTDMA-CCNC setup. This example is for a dry size of $75 \mathrm{~nm}$ and a GF of 1.48 . The black line is fitted to the data in the range $\mathrm{AF}=0.3-0.7$. The purple tringle shows $\mathrm{SS}_{\mathrm{crit}}(D, \mathrm{GF})$ at $\mathrm{AF}=0.5$ and the purple error bars indicate the $\mathrm{SS}$ range between $\mathrm{AF}=0.3$ and $\mathrm{AF}=0.7$.

For the HTDMA-CCNC coupled setup the data analysis was done differently. The main difficulty was that the particles were passed through 2 DMAs and therefore the detected particle number concentrations both in the CPC and CCNC were very low, e.g. the average (over time and SS) $n_{\mathrm{CCN}}$ was as low as $0.21 \mathrm{~cm}^{-3}$. This results in very low counting statistics and high measurement uncertainty. To overcome this problem the single scan results were time averaged over the whole 13-days measurement period, and with this the AF was obtained as a function of the three independent parameters SS, GF and $D$. Due to the many parameters that were varied, the AF scans did not always capture the whole activation process (from none to full activation), and even after time averaging still significant noise was present. Therefore we used the following method to determine the $\mathrm{SS}_{\text {crit }}(D, \mathrm{GF})$ values (see Fig. 3 for an example): a linear fit was done on a logarithmic SS scale between $\mathrm{AF}(\mathrm{SS}, \mathrm{GF}, D)=0.3$ and $\mathrm{AF}(\mathrm{SS}, \mathrm{GF}, D)=0.7$ at fixed $\mathrm{GF}$ and $D$. This fit was then used to determine $\operatorname{SS}_{\text {crit }}(D, \mathrm{GF})$, which is defined as $\mathrm{AF}\left(\mathrm{SS}_{\text {crit }}(D, \mathrm{GF}), \mathrm{GF}, D\right)=0.5$. No correction was made here for the effect of the multiply charged particles. Therefore we made a conservative error estimate by using $\operatorname{AF}\left(D, S_{\text {crit, low }}, \mathrm{GF}\right)=0.3$ and $\operatorname{AF}\left(D, S_{\text {crit, high }}, \mathrm{GF}\right)=0.7$ to determine $\mathrm{SS}_{\text {crit, low }}$ and $\mathrm{SS}_{\text {crit, high, }}$, respectively, which represents the uncertainty range of $\mathrm{SS}_{\text {crit }}(D, \mathrm{GF})$.

\subsection{Mixing-state resolved hygroscopicity closure}

The GF-PDFs at $90 \%$ RH measured by the HTDMA for different dry sizes were used to predict the complete $\operatorname{AF}(D, \mathrm{SS})$ size distributions that would be obtained by the monodisperse $\mathrm{CCN}$ measurements. We used the methodology introduced by Kammermann et al. (2010b) in order to do so. The activated fraction of the particles as a function of supersaturation, dry size and time is calculated as follows:

$$
\operatorname{AF}_{\text {HTDMA }}(D, \mathrm{SS}, t)=\int_{\mathrm{GF}_{\text {crit }}(\mathrm{D}, \mathrm{SS})}^{\infty} h(D, \mathrm{GF}, t) d \mathrm{GF}
$$

where $h(D, \mathrm{GF}, t)$ is the GF-PDF, and $\mathrm{GF}_{\text {crit }}(D, \mathrm{SS})$ is the critical growth factor (hygroscopicity), above which particles with dry diameter $D$ act as $\mathrm{CCN}$ at a defined SS. $\mathrm{GF}_{\text {crit }}(D, \mathrm{SS})$ was calculated using the $\kappa$-Köhler theory as introduced in Sect. 3.1, thereby assuming the surface tension of pure water. This approach delivers the $\operatorname{AF}_{\mathrm{HTDMA}}(D, \mathrm{SS}, t)$ size distribution derived from the HTDMA measurement, which can directly be compared with the $\operatorname{AFCCNC}_{\mathrm{C}}(D, \mathrm{SS}, t)$ size distribution obtained from the monodisperse CCN measurement in order to test whether a mixing-state resolved closure is achieved between sub- and supersaturation. The HTDMA measurements were done only at 6 different dry diameters, whereas one CCNC D-scan resulted in 27 data points of $\operatorname{AF}_{\mathrm{CCNC}}\left(D_{i}, \mathrm{SS}\right)$ for each supersaturation (after binning and inversion). Therefore the GF-PDFs were linearly interpolated in between the dry diameters of the HTDMA measurements and the diameter grid of the inverted CCN measurements. The GF-PDF was further assumed to be constant below the smallest $(35 \mathrm{~nm})$ and above the largest $(265 \mathrm{~nm})$ mobility diameters covered by the HTDMA measurement. In order to derive the $\mathrm{AF}_{\mathrm{HTDMA}}(D, \mathrm{SS}, t)$ size distribution, the HTDMA measurements at all 6 dry diameters were needed, and the full diameter cycle has a time resolution of $\sim 1 \mathrm{~h}$, whereas one $\operatorname{AF}_{\mathrm{CCNC}}(D, \mathrm{SS})$ scan with the CCNC lasted only $300 \mathrm{~s}$. Therefore GF-PDFs were also interpolated in time, which adds uncertainty if the hygroscopic properties of the urban aerosol vary substantially on a shorter timescale.

An equivalent closure approach, not followed in this study, would be to compare measured and predicted GF-PDFs, i.e. to predict the GF-PDFs from the $\operatorname{AF}_{\mathrm{CCNC}}(D, \mathrm{SS})$ obtained from the monodisperse $\mathrm{CCN}$ measurements.

\section{Results and discussion}

\subsection{CCN number concentrations and $\mathrm{CCN}$ number size distributions}

Total CCN number concentrations were measured at the SIRTA site in Paris during February 2010 in two alternative ways (Fig. 1a). $N_{\mathrm{CCN}}(\mathrm{SS})$ was directly obtained for five SS from the polydisperse CCNC. $N_{\mathrm{CCN}}(\mathrm{SS})$ can also be obtained by integration of the $\mathrm{CCN}$ number size distribution measurement of the scanning diameter setup. $\mathrm{CCN}$ larger than the upper size limit of the size distribution measurement $(413 \mathrm{~nm})$ are not considered with this approach. However, the shape of $n_{\mathrm{CCN}}(\mathrm{SS}, D)$ (see below, Fig. 5) indicates that only a very small number fraction is missed in this way, except for a slightly larger bias $(\sim 14 \%)$ at the lowest SS $(0.1 \%)$. 


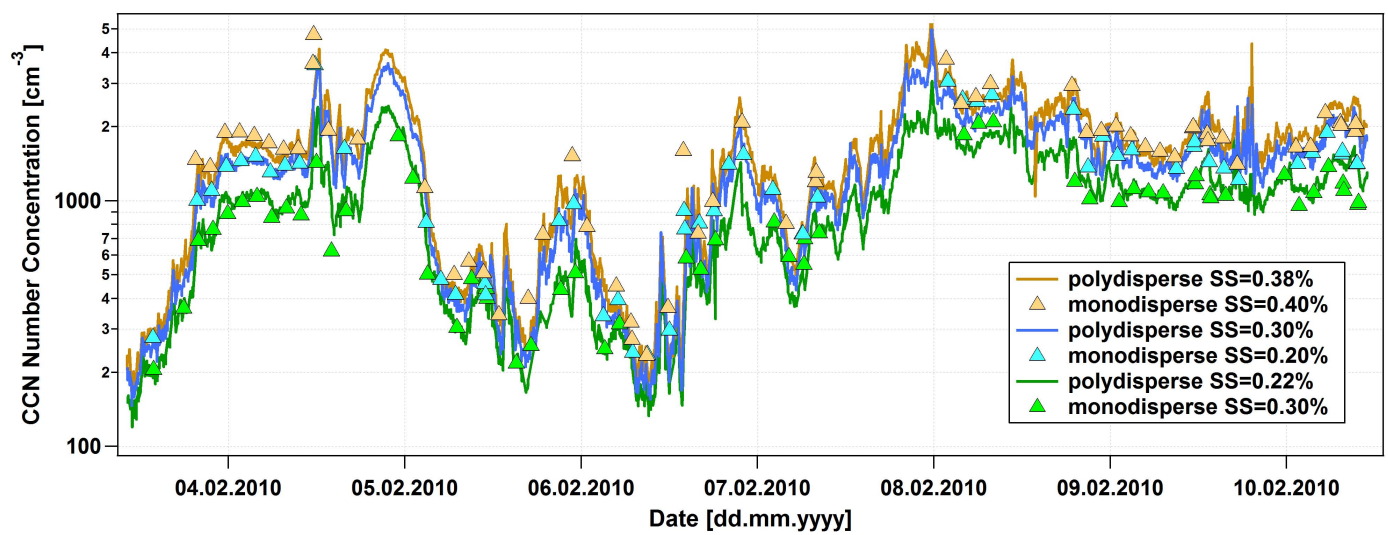

Fig. 4. SS dependent $\mathrm{CCN}$ number concentration from the direct polydisperse measurement (lines) and from the integrated $\mathrm{CCN}$ number size distribution measurements (triangles).

Table 1. The average, minimum, maximum and standard deviation values of $N_{\mathrm{CCN}}$ at the different $\mathrm{SS}$ as determined from the scanning CCNC.

\begin{tabular}{lcccr}
\hline $\begin{array}{l}\text { SS } \\
{[\%]}\end{array}$ & $\begin{array}{c}\text { Avg } \\
{\left[\mathrm{cm}^{-3}\right]}\end{array}$ & $\begin{array}{c}\text { Min } \\
{\left[\mathrm{cm}^{-3}\right]}\end{array}$ & $\begin{array}{c}\text { Max } \\
{\left[\mathrm{cm}^{-3}\right]}\end{array}$ & $\begin{array}{r}\text { Stdev } \\
{\left[\mathrm{cm}^{-3}\right]}\end{array}$ \\
\hline 0.1 & 653 & 79 & 1520 & 302 \\
0.2 & 1119 & 205 & 2345 & 542 \\
0.3 & 1603 & 236 & 3746 & 835 \\
0.4 & 1930 & 234 & 4739 & 978 \\
0.5 & 2248 & 276 & 5545 & 1122 \\
0.6 & 2646 & 415 & 7329 & 1368 \\
0.7 & 2655 & 371 & 5868 & 1305 \\
0.8 & 2968 & 475 & 6473 & 2968 \\
0.9 & 3002 & 558 & 6906 & 1465 \\
1.0 & 3406 & 835 & 7568 & 1548 \\
\hline
\end{tabular}

The method of deriving $N_{\mathrm{CCN}}(\mathrm{SS})$ from size-resolved measurements is often used (e.g. Gunthe et al., 2011). The opportunity of having parallel polydisperse and monodisperse $\mathrm{CCN}$ measurements in this study allows for testing the precision of $N_{\mathrm{CCN}}(\mathrm{SS})$ obtained by integrating $\mathrm{CCN}$ number size distributions. Figure 4 presents such a comparison for three almost agreeing SS pairs of the two CCNCs ( $\mathrm{SS}=0.38 \%$ and $0.40 \%, \mathrm{SS}=0.30 \%$ and $0.30 \%$, as well as $\mathrm{SS}=0.22 \%$ and $0.20 \%$ ). The observed agreement is very good. The two methods correlate with slopes of $0.96,0.99$ and $1.05\left(R^{2}=0.75,0.76\right.$ and 0.84$)$ for the three SS pairs, respectively. The small negative and positive deviations from unit slope are in agreement with the small negative and positive differences in the applied SS in the two CCNCs at the nominal SS of $0.4 \%$ and $0.2 \% \mathrm{SS}$, respectively. This result confirms the high precision of the indirect monodisperse method for $\mathrm{CCN}$ measurements, which is not surprising as good performance of the monodisperse approach has previously been shown for particle number size distribution mea-

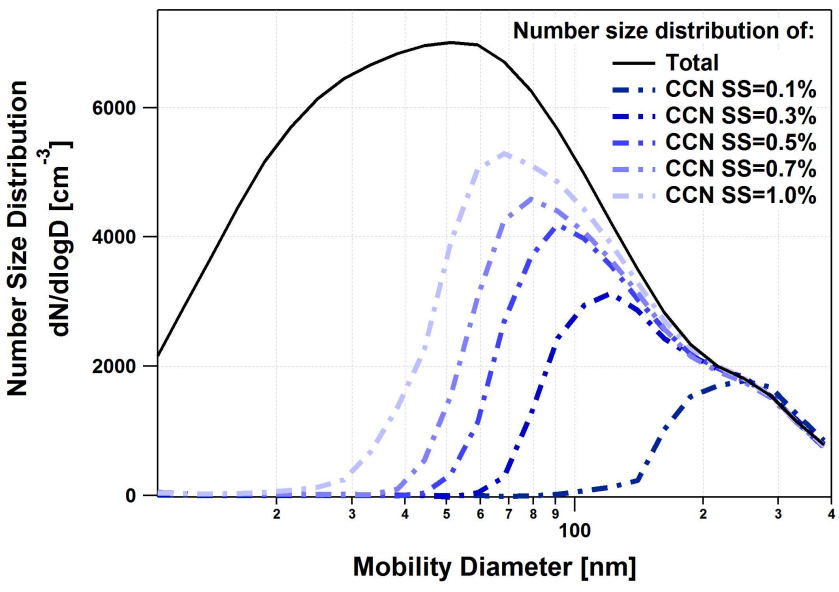

Fig. 5. Particle $\left(n(D)\right.$, black line) and $\mathrm{CCN}\left(n_{\mathrm{CCN}}(D, \mathrm{SS})\right.$, blue dashed-dotted lines) number size distributions averaged over the 10days' measurement period.

surements (Wiedensohler et al., 2012). However, it has to be emphasized that this only applies if the raw data of the monodisperse measurement are appropriately inverted in order to account for DMA transfer probability, charging probability and multiply charged particles.

The average, minimum, maximum and standard deviation values of the $\mathrm{CCN}$ number concentration at the different $\mathrm{SS}$ are presented in Table 1 . Average $N_{\mathrm{CCN}}$ increases considerably with increasing SS, i.e. from $653 \mathrm{~cm}^{-3}$ at $\mathrm{SS}=$ $0.1 \%$, through $2248 \mathrm{~cm}^{-3}$ at SS $=0.5 \%$, to $3406 \mathrm{~cm}^{-3}$ at $\mathrm{SS}=1.0 \%$. The temporal variability of $N_{\mathrm{CCN}}$ at a constant SS is also considerable with ratios of 9-20 between maximum and minimum values and relative standard deviations of $46-52 \%$. Based on this, we can state that even if the measurement period was only 10 days, the $\mathrm{CCN}$ number concentration experienced significant variability as a function of both time and SS. 


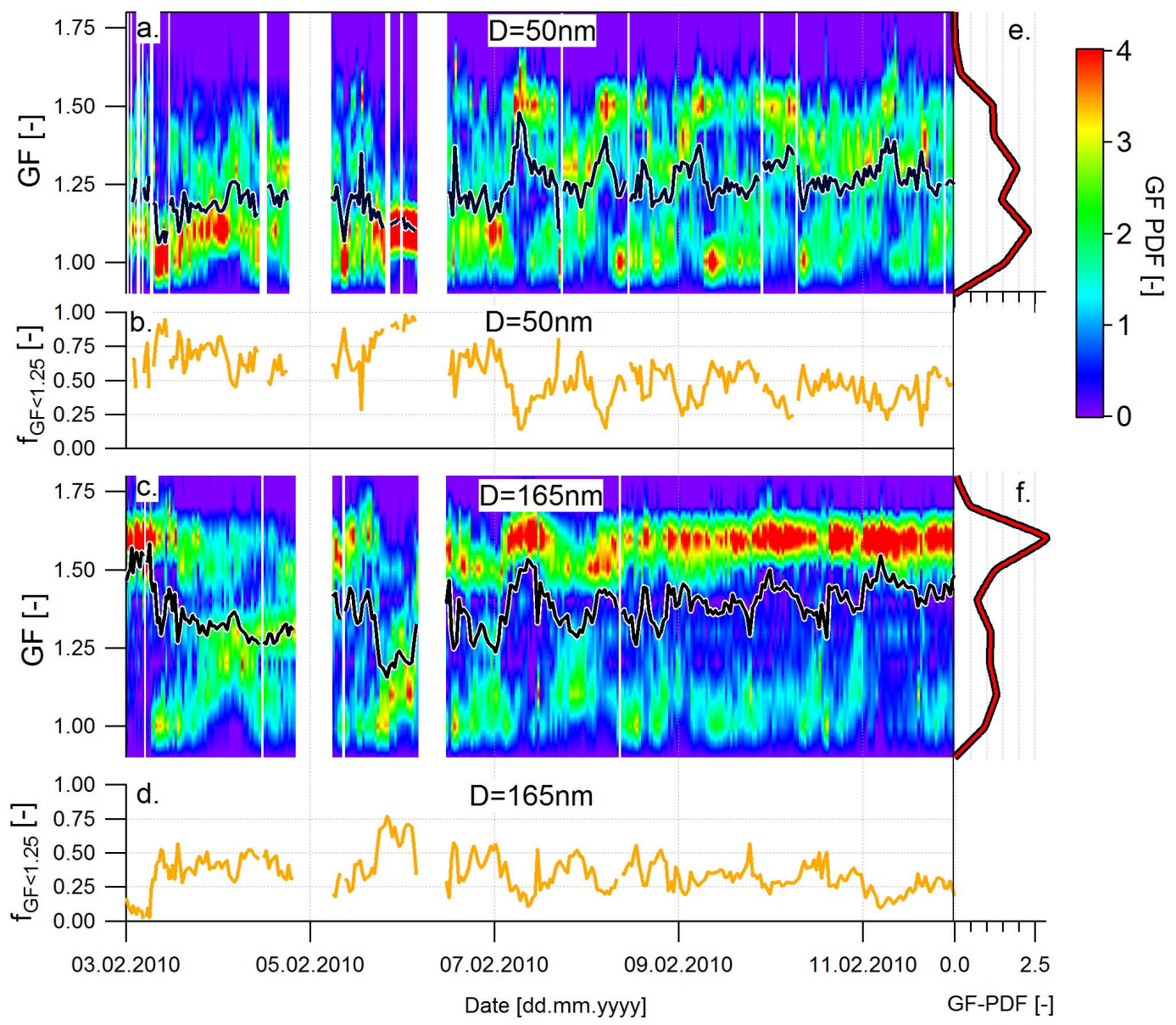

Fig. 6. Time series of the hygroscopic properties at $90 \% \mathrm{RH}$ for the two example dry sizes $D=50 \mathrm{~nm}(\mathbf{a}$ and $\mathbf{b})$ and $D=165 \mathrm{~nm}(\mathbf{c}$ and d). The GF-PDFs are shown as image plots on panels (a) and (c), and the black lines indicate the corresponding mean GF. The time-averaged GF-PDFs (black-red lines) are found on the right side of the graph (e and f). The orange lines on panels (b) and (d) represent the number fraction of the particles having a GF smaller than 1.25 .

The inverted $\mathrm{CCN}$ and particle number size distributions, averaged over the 10-day measurement period, are displayed in Fig. 5. The majority of the particles were relatively small with a median diameter of the particle number size distribution of $\sim 45 \mathrm{~nm}$. As expected, even at the highest SS (SS= $1 \%$, lightest blue line in Fig. 5), the smallest particles are not activated. As the SS decreases, the lower cut-off diameter of the $\mathrm{CCN}$ number size distribution is shifted towards larger diameters. The particle and CCN number size distributions agree for the largest diameters (above 150-250 nm depending on the supersaturation), indicating complete activation of all particles in this diameter range. The $\mathrm{CCN}$ number size distributions at the lower diameters do not increase sharply from zero activation to complete activation, as it would occur for a single component or perfectly internally mixed aerosol; instead the transition happens within a 120-200 nm wide mobility diameter range, depending on the supersaturation. The broad width of the activation cut-off is to some extent an artificial effect caused by averaging in time; however, it will be shown below that it is, to a great extent, due to the external mixing state of the aerosol (Sects. 4.2 and 4.3).

\subsection{Mixing state measured at subsaturation}

Laborde et al. (2013) used the HTDMA data set from the SIRTA site during this campaign to investigate particle hygroscopicity for different air mass types. The background aerosol was characterized by a dominant hygroscopic mode, peaking at a GF of $\sim 1.6$ at $\mathrm{RH}=90 \%$. In contrast, the road traffic emissions were essentially non-hygroscopic with a GF of 1.0, in agreement with Baltensperger et al. (2002), while biomass burning emissions resulted in a less hygroscopic mode peaking at a GF of $\sim 1.1-1.2$. Particles with intermediate GF in the range 1.3-1.5 were also present, though only contributing a minor number fraction at particle diameters larger than $110 \mathrm{~nm}$.

The time series of the GF-PDFs for $D=50 \mathrm{~nm}$ and $165 \mathrm{~nm}$ shown in Fig. 6 reveals that the Paris aerosol is often 

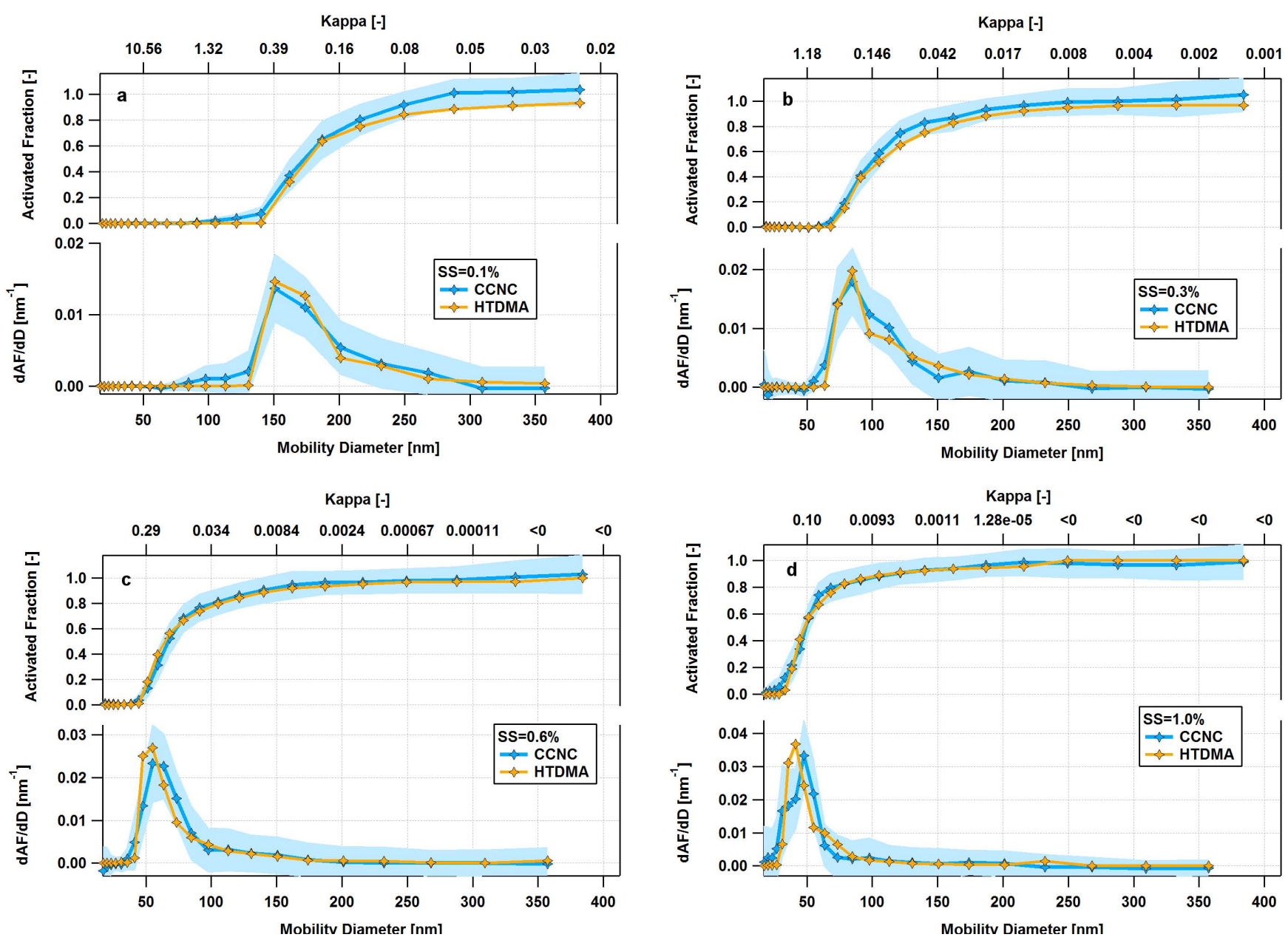

Fig. 7. Time-averaged $\mathrm{AF}(D)$ and $\partial \mathrm{AF}(D, \mathrm{SS}) / \partial D$ as measured by the CCNC (blue markers and lines) and as derived from the HTDMA measurement (orange markers and lines) at 4 example SS $(0.1,0.3,0.6$ and $1 \%)$. The blue shading represents the standard deviation of the CCNC measurements. The top axis shows, for illustration, the $\kappa$ hygroscopicity parameters that correspond to the set SS value and the dry diameter from the bottom axis; note that the $\kappa$ values represent the hygroscopicity for changing dry particle diameter.

highly externally mixed, with simultaneous occurrence of two or more of the above-mentioned particle types. The mean GF (black lines in Fig. 6a and c) exhibits considerable temporal variability, which is mostly driven by the relative abundance of background aerosol and fresh emission from road traffic and biomass burning, as revealed by the strong anticorrelation of the mean GF with the number fraction of particles with GF $<1.25$ (orange lines in Fig. $6 \mathrm{~b}$ and d). The timeaveraged GF-PDFs for $D=50$ and $165 \mathrm{~nm}$ are shown in Fig. $6 \mathrm{e}$ and $\mathrm{f}$. Two features regarding the size-dependence of the particle hygroscopicity are noteworthy: the background aerosol peaks at a lower GF at smaller particle sizes and the number fraction of non- and less hygroscopic particles with $\mathrm{GF}<1.25$ is higher for smaller particles.

Based on the facts mentioned above, we can state that during this 10-day measurement period the aerosol was highly externally mixed and both the shape and the average of the GF-PDF were substantially variable in time. The mean $\kappa$ hygroscopicity parameter had values in the range $0.12-0.27$ and increased with increasing dry diameter in the range 35$265 \mathrm{~nm}$. More details on particle hygroscopicity, the chemical composition, as well as the mixing state of $\mathrm{BC}$ particles during MEGAPOLI campaigns in Paris can be found elsewhere (Tritscher, 2011; Crippa et al., 2013; Laborde et al., 2013).

\subsection{Mixing state measured at supersaturation}

Figure 7 contains the campaign average of the AF size distribution ( $\mathrm{AF}(D, \mathrm{SS})$; top panels) and the partial derivative of $\mathrm{AF}(D, \mathrm{SS})$ by diameter $(\partial \mathrm{AF}(D, \mathrm{SS}) / \partial D$; bottom panels) for four example SS $(0.1,0.3,0.6$ and $1.0 \%) . \partial \mathrm{AF}(D, \mathrm{SS}) / \partial D$, the distribution of the critical dry diameter at a certain SS, reflects the hygroscopicity distribution of the particles. $\partial \mathrm{AF}(D, \mathrm{SS}) / \partial D$ is narrow for internally mixed aerosols, 
whereas it is wide and/or has multiple modes for externally mixed aerosols.

We now focus on the blue lines in Fig. 7, which show the size-dependence of the activation behaviour as directly obtained from the inverted monodisperse $\mathrm{CCN}$ measurements (Sect. 3.2). The top axis of all panels in Fig. 7 shows the $\kappa$ values corresponding to the diameter scale for each supersaturation. The monodisperse $\mathrm{CCN}$ measurement clearly shows that complete activation $(\mathrm{AF}(D, \mathrm{SS})=1)$ is reached within uncertainty at $\kappa \geq 0$ at all SS. This indicates the absence of a significant fraction of hydrophobic, non-wettable particles during the measurement period.

The transition between completely $\mathrm{CCN}$ inactive $(\mathrm{AF}=0)$ and $\mathrm{CCN}$ active $(\mathrm{AF}=1)$ particle sizes extends over a wide diameter range for all supersaturations, and consequently $\partial \operatorname{AF}(D, \mathrm{SS}) / \partial D$ has a substantial width. This reveals that the urban aerosol in Paris is either externally mixed and/or that the $\mathrm{CCN}$ activity varies in time. The HTDMA measurements presented in Sect. 4.2 and Fig. 6 have already shown that the aerosol is indeed often externally mixed.

Statistics of the CCN-derived mixing state derived from all individual measurements are presented in Table 2. A quantitative measure of the degree of external mixture is obtained from the relative width of the activated fraction distribution, expressed as the ratio $\left(D_{75}-D_{25}\right) / D_{50} . D_{X}$ is here defined as the diameter at which $X \%$ of the particles are $\mathrm{CCN}$ active (i.e. $\operatorname{AF}\left(D_{X}\right)=X \%$ ). The last column in Table 2 shows that the ratio $\left(D_{75}-D_{25}\right) / D_{50}$ is $0.08-0.12$ for ammonium sulphate calibration measurements across all supersaturations. Values of $\left(D_{75}-D_{25}\right) / D_{50} \leq 0.12$ therefore indicate an internal mixture within the resolving power of the experimental setup, whereas larger values indicate external mixture. For the ambient aerosol in Paris, the mean value of $\left(D_{75}-D_{25}\right) / D_{50}$ increases from 0.27 at $\mathrm{SS}=0.1 \%$ to 0.81 at $\mathrm{SS}=1 \%$, and the standard deviation of $\left(D_{75}-D_{25}\right) / D_{50}$ increases concurrently. This shows that the degree of external mixture and the variability of the mixing state increases with decreasing particle size. Laborde et al. (2013) observed during the same campaign in Paris that the relative influence of local particle sources on the total aerosol loading increases with decreasing particle size, while the influence of the aged background aerosol increases with increasing particle size. This is consistent with the size-dependence of the hygroscopic mixing state observed in this study.

The activation behaviour of an externally mixed aerosol often needs to be described with a single number, e.g. for modelling purposes or for comparing different measurements. In Table 2 we also report the statistics of $D_{50}$ (the diameter at which $50 \%$ of the particles are $\mathrm{CCN}$ active) and of the geometric mean diameter $\left(D_{\text {geom }}\right)$ of the time averaged $\partial \mathrm{AF} / \partial D$ for the ambient aerosol in Paris. The mean values of $D_{50}$ and $D_{\text {geom }}$ match each other well across all supersaturations. This cannot necessarily be expected, as substantial discrepancies could in principle occur if the aerosol is an external mixture of two or more well-separated hygroscopic-

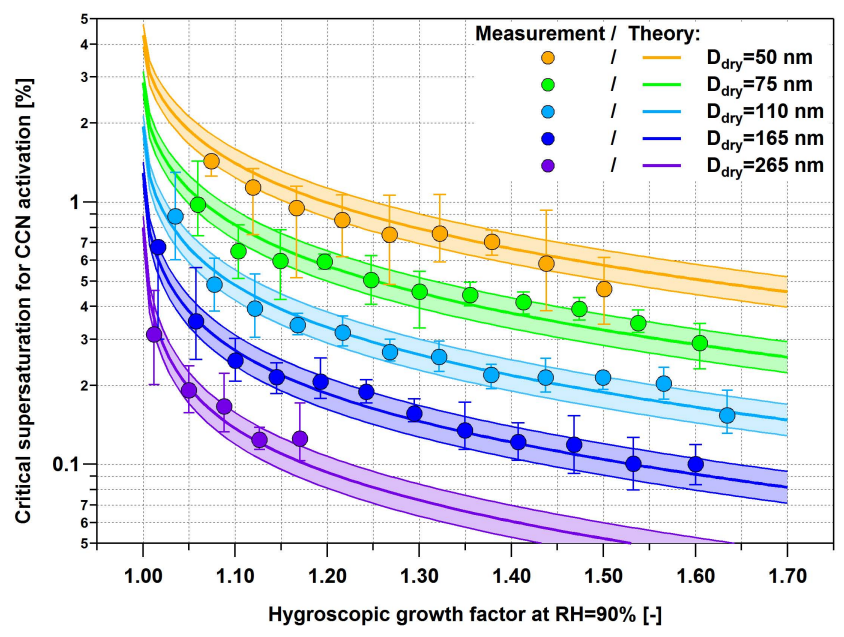

Fig. 8. Theoretical and measured $\mathrm{SS}_{\text {crit }}$ values as a function of GF. The different colours represent the different dry diameters. Theoretical curves (solid lines) were calculated using $\kappa$-Köhler theory and assuming the surface tension of pure water at the point of activation. The shading around the theoretical curves indicates the effect of varying the surface tension by $\pm 10 \%$ compared to that of pure water. The measured data points (filled circles) represent the supersaturation at which an activated fraction of $50 \%$ was measured for a certain dry diameter and growth factor. The error bars indicate the corresponding supersaturation range between $30 \%$ and $70 \%$ activation.

ity modes. Table 2 also contains the $\kappa$ values $\left(\kappa_{\text {geom }}\right)$ corresponding to $D_{\text {geom. }} D_{\text {geom }}$ rather than $D_{50}$ was chosen to calculate the representative $\kappa$ value, as assuming a sharp CCN activation cut-off at $D_{\text {geom }}$ provides the correct $\mathrm{CCN}$ number concentration for any kind of external mixture if $\mathrm{d} N / \mathrm{d} \log D$ is approximately constant across the diameter range of the activation cut-off (i.e. between $\operatorname{AF}(D)=0$ and $\operatorname{AF}(D)=1$ ). $\kappa$ geom increased from $\sim 0.1$ at diameters between $50 \mathrm{~nm}$ and $90 \mathrm{~nm}$ through $\sim 0.16$ at $127 \mathrm{~nm}$ to $\sim 0.24$ at $174 \mathrm{~nm}$. This is consistent with the $\kappa$ values derived from the measurements at subsaturation (Sect. 4.2). The $\kappa$ values observed in this study for the wintertime aerosol in Paris are, for particle diameters below $127 \mathrm{~nm}$, substantially lower than the value of 0.3 , which is suggested by Andreae and Rosenfeld (2008) and Pringle et al. (2010) for an average continental aerosol.

\subsection{Validation of the $\kappa$-Köhler theory with a coupled HTDMA-CCNC setup}

One goal of this study was to test the applicability of the $\kappa$-Köhler theory for linking the hygroscopic growth of particles below water vapour saturation with their $\mathrm{CCN}$ activity at supersaturation. Here we show a stringent test of $\kappa$ Köhler theory by directly measuring the critical supersaturation for $\mathrm{CCN}$ activation of particles with a well-defined dry diameter and hygroscopic growth factor. This was achieved by coupling the CCNC to the HTDMA (see Sect. 2.2.3 for 
Table 2. Properties of the CCNC-derived hygroscopicity distributions for ambient and ammonium sulphate (AS) aerosols. $D_{50}$ (time average \pm standard deviation) is the diameter at which $50 \%$ of the particles are activated, $\left(D_{75}-D_{25}\right) / D_{50}$ (time average \pm standard deviation) represents the width of the AF distribution, $D_{\text {geom }}$ is the geometric mean activation diameter and $\kappa$ geom is the $\kappa$ value derived from $D_{\text {geom. }}$

\begin{tabular}{lccccc}
\hline & \multicolumn{2}{c}{ Ambient } & AS \\
SS [\%] & $D_{50}[\mathrm{~nm}]$ & $\left(D_{75}-D_{25}\right) / D_{50}[-]$ & $D_{\text {geom }}[\mathrm{nm}]$ & $\kappa_{\text {geom }}[-]$ & $\left(D_{75}-D_{25}\right) / D_{50}[-]$ \\
\hline 0.1 & $177 \pm 18$ & $0.27 \pm 0.10$ & 174 & 0.24 & 0.08 \\
0.2 & $127 \pm 14$ & $0.40 \pm 0.13$ & 126 & 0.16 & 0.12 \\
0.3 & $100 \pm 14$ & $0.51 \pm 0.27$ & 106 & 0.12 & 0.09 \\
0.4 & $88 \pm 15$ & $0.53 \pm 0.30$ & 90 & 0.10 & 0.11 \\
0.5 & $76 \pm 12$ & $0.61 \pm 0.43$ & 77 & 0.11 & 0.11 \\
0.6 & $69 \pm 12$ & $0.70 \pm 0.50$ & 71 & 0.10 & 0.12 \\
0.7 & $64 \pm 13$ & $0.44 \pm 0.43$ & 67 & 0.08 & 0.11 \\
0.8 & $60 \pm 12$ & $0.66 \pm 0.43$ & 57 & 0.11 & 0.10 \\
0.9 & $56 \pm 13$ & $0.71 \pm 0.50$ & 54 & 0.10 & 0.12 \\
1.0 & $50 \pm 10$ & $0.81 \pm 0.72$ & 49 & 0.11 & 0.12 \\
\hline
\end{tabular}

details) for the period from 16 January to 29 January 2010. The key advantage of this approach is that the measurement is not affected by short-term variability of various aerosol properties, which is a potential issue for many other closure approaches in urban environments. The disadvantage is that long measurement times are required to cover the whole three-dimensional parameter space (supersaturation, dry diameter, hygroscopic growth factor; see Sect. 3.2). For this reason the result averaged over the whole period from 16-29 January 2010 is presented in Fig. 8.

The thick solid lines were calculated using $\kappa$-Köhler theory (see Sect. 3.1), assuming surface tension of pure water and assuming that the $\kappa$ value is independent of the water content of the particle. The width of the shading around the theoretical lines represents the effect of varying the surface tension by $\pm 10 \%$ compared to that of pure water (constant $\kappa$ value), which is equivalent to a change of the $\kappa$ value by $\sim \pm 30 \%$ between $\mathrm{RH}=90 \%$ and the activation point (at constant surface tension of pure water). The values measured by the CCNC (filled circles) agree well with $\kappa$-Köhler theory for all supersaturations, dry diameters and growth factors: almost all data points are within the shaded regions. This means that the $\kappa$-Köhler theory with the assumption of the surface tension of pure water is quite applicable to describe the link between the hygroscopic growth of particles below water vapour saturation and their $\mathrm{CCN}$ activity at supersaturation for a wide range of dry diameters, particle hygroscopicities and critical supersaturations. This successful mixing-state resolved hygroscopicity- $\mathrm{CCN}$ closure is in contrast to other studies in urban locations, where closure was not achieved with $\kappa$-Köhler theory (Cubison et al., 2008; Ervens et al., 2010). Potential reasons for this disagreement can be of experimental nature, e.g. limited time or size resolution of the measurements or experimental issues such as, e.g. modification of particle properties in one of the instruments by evaporation of semi-volatile species after drying (Gysel et al., 2007). However, physical effects can also cause a disagreement. Possible effects are liquid-liquid phase separation (Bertram et al., 2011), surface-bulk partitioning of surface active compounds (Sorjamaa et al., 2004), or co-condensation of semi-volatile vapours (Hegg, 2000). It remains an open question for atmospheric aerosols under which conditions or in which environments such effects typically occur and how frequent they are.

Figure 8 also shows both theoretically and experimentally a sharp increase of the critical supersaturation for $\mathrm{CCN}$ activation at growth factors below $\sim 1.1$. Consequently these non- and marginally hygroscopic particles, which are often associated with black carbon containing particles (McMeeking et al., 2011; Laborde et al., 2013), have a strong competitive disadvantage for $\mathrm{CCN}$ activation, which reduces their wet-removal efficiency by in-cloud scavenging compared to medium and strongly hygroscopic particles.

\subsection{Mixing-state resolved hygroscopicity-CCN closure}

The analysis presented in Sect. 4.4 shows that $\kappa$-Köhler theory does explain the link between hygroscopic growth and $\mathrm{CCN}$ activation on average. This section aims at verifying that monodisperse $\mathrm{CCN}$ measurements provide accurate information of the mixing state of the aerosol and that mixing state resolved closure between hygroscopic growth and CCN activation is achieved at any time.

The orange lines in Fig. 7 show the predictions made from the GF-PDFs measured by the HTDMA at water vapour subsaturation (Sect. 3.3). Excellent agreement of the CCN activation behaviour predictions derived from the GF-PDFs (HTDMA measurement) with the direct monodisperse CCN measurement was achieved. This does not only apply to the four SS shown in Fig. 7 but also to the other six investigated 

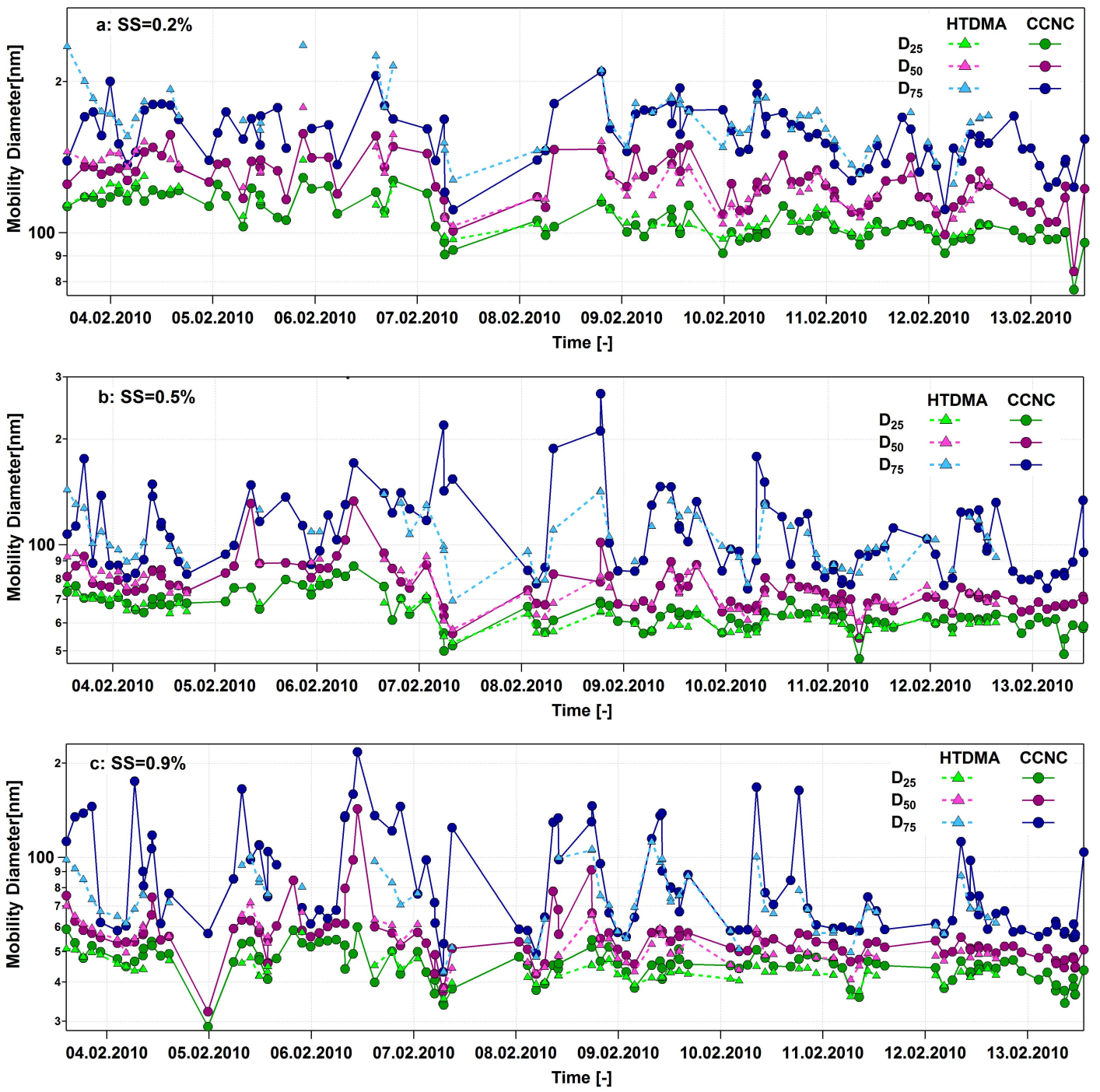

Fig. 9. The time evolution of $D_{25}, D_{50}$ and $D_{75}$ of the $D_{\text {crit }}$ distributions ( $\left.\partial \mathrm{AF} / \partial D\right)$ at $0.2 \%$ (a), $0.5 \%$ (b) and $0.9 \%$ (c) SS as measured by the CCNC (filled circles) and predicted by the HTDMA (filled triangles).

SS (not shown). However, slightly larger differences between measurement and prediction are observed at the highest SS (1\%; Fig. 7d). No particular reason for this small bias could be identified. The success of the mixing-state resolved hygroscopicity-CCN closure shown in Fig. 7 confirms the applicability of the $\kappa$-Köhler theory, as independently shown with the results from coupled HTDMA-CCNC setup (Sect. 4.4, Fig. 8). The successful closure further shows that it is possible to derive the hygroscopic mixing state of an aerosol from size-resolved CCN measurements.

The results presented above show that monodisperse $\mathrm{CCN}$ measurements can provide detailed and precise information about the mixing state of the aerosol averaged over 10 days of measurements. The capability of this approach to capture the short-term variability of the aerosol mixing state remains to be addressed. In order to do so, the $D_{25}, D_{50}$ and $D_{75}$ val- ues from all individual monodisperse $\mathrm{CCN}$ size distribution scans are compared with those predicted from the HTDMA derived GF-PDFs interpolated to the same time. Figure 9 shows the time evolution of the $D_{25}, D_{50}$ and $D_{75}$ for a low $(0.2 \%)$, a medium $(0.5 \%)$ and a high $(0.9 \%)$ SS. This comparison reveals good agreement between the time-resolved CCNC and HTDMA derived mixing-state data. The slopes of the orthogonal linear regression (forced through the origin) of the correlations between the CCNC and HTDMA derived mixing-state data, including all $10 \mathrm{SS}$ results in slopes of 1.00, 1.01 and 1.04 with correlation coefficients $\left(R^{2}\right)$ of $0.98,0.97$ and 0.69 for the $D_{25}, D_{50}$ and $D_{75}$ values, respectively. This shows that monodisperse $\mathrm{CCN}$ size distribution measurements are suitable to derive the mixing state of an aerosol with high time resolution. 
The fact that the correlation coefficient is the lowest for $D_{75}$ can most likely be attributed to limited counting statistics of the particle and CCN number size distribution measurements at larger particle diameters. The particle number size distribution peaks (on average) at a diameter of $\sim 50 \mathrm{~nm}$, such that $D_{75}$, which typically takes diameter values between 60-200 nm, depending on SS (Fig. 9), falls often into the tail of the particle number size distribution. As a consequence, $D_{75}$ is associated with larger measurement noise. $D_{75}$ values derived from HTDMA measurements are slightly less noisy than those derived from the CCNC measurement, indicating that the HTDMA is a little more sensitive for detecting the aerosol mixing state with high time resolution compared to the monodisperse $\mathrm{CCNC}$ measurements. This is likely due to the much lower sample flow rate in the CCNC $\left(50 \mathrm{~cm}^{3} \mathrm{~min}^{-1}\right)$ compared to the HTDMA $\left(300 \mathrm{~cm}^{3} \mathrm{~min}^{-1}\right)$, which results in better counting statistics for the HTDMA. However, no significant difference in terms of sensitivity is observed for $D_{25}$ and $D_{50}$. In summary, the sensitivity of the two methods and the agreement between them is astonishingly good, given that the aerosol is highly variable in Paris and that $\kappa$-Köhler theory, which is just an approximation, is used to compare them.

\section{Conclusions}

In one experiment, the CCNC was directly coupled to the HTDMA, which allowed selecting particles by their dry size and hygroscopicity before probing their CCN activity. This made a stringent test of the $\kappa$-Köhler theory, which also considers the hygroscopic mixing state of the aerosol, possible for the highly variable and externally mixed aerosol of urban Paris. It was shown that the $\kappa$-Köhler theory, with assuming surface tension of pure water, connects the hygroscopic growth of particles at $90 \% \mathrm{RH}$ with their $\mathrm{CCN}$ activity at supersaturation in a highly accurate manner. The novelty of this approach is that closure was achieved for a wide range of the three-dimensional parameter space constituted by dry diameter, particle hygroscopicity (composition) and supersaturation.

In another experiment, a monodisperse scanning diameter CCNC setup was operated in parallel with a polydisperse $\mathrm{CCNC}$ and an HTDMA. The CCN number concentrations measured by the polydisperse $\mathrm{CCNC}$ and the integrated $\mathrm{CCN}$ number concentrations from the $\mathrm{CCN}$ number size distributions measured by the monodisperse CCNC agreed well for different supersaturations. This shows that monodisperse $\mathrm{CCN}$ measurements are a valid alternative for the measurement of total CCN number concentrations, given that appropriate corrections for the transfer probability of the DMA, the charging probability and the effects of multiply charged particles are applied.
The main purpose of the monodisperse $\mathrm{CCN}$ measurements in this study was to determine the hygroscopic mixing state of the aerosol. A detailed comparison between the measured size dependence of CCN activation across a wide range of supersaturations with that predicted from GF-PDFs at $90 \% \mathrm{RH}$ as measured by the HTDMA revealed excellent agreement, also for highly time-resolved data $(1 \mathrm{~h}$ timeresolution). This successful closure confirms again the suitability of the $\kappa$-Köhler theory and it further shows experimentally, for the first time to our knowledge, that monodisperse CCNC measurements are a reliable method for the measurement of the aerosol mixing state.

The good results of the above closure studies are particularly notable as they are achieved at a site close to Paris. The aerosol at this site is highly variable in time, often externally mixed, and has been shown in a parallel study to be influenced to a variable degree by background aerosol as well as fresh emissions from road traffic and biomass burning. This shows the suitability of the $\kappa$-Köhler theory for different aerosols with a wide range of hygroscopic properties. These results have important implications for the interpretation of other hygroscopicity closure studies in urban environments, where sometimes significant differences in hygroscopicity$\mathrm{CCN}$ closure studies were found. In such cases one should carefully check whether the differences are caused by experimental reasons (e.g. insufficient time and/or size resolution, residence time effects or changes to the aerosol particles that could for example be associated with the drying required for the measurements) or true physical effects such as liquid-liquid phase separation, surface-bulk partitioning of surface active compounds or co-condensation of semivolatile vapours. It remains an open question regarding atmospheric aerosols under which conditions or in which environments such effects typically occur and how frequent they occur.

Acknowledgements. This research was performed in the context of the MEGAPOLI project and was financially supported by the European Community's Framework Program FP/2007-2011 under grant agreement no. 212520. Financial support was also received from the Swiss National Science Foundation and from MeteoSwiss within the framework of the Global Atmosphere Watch program. SIRTA and LHVP are particularly thanked for their strong support in the field. Laurent Gomes sadly passed away during the preparation of this manuscript. We thank Laurent for his valuable input and dedicate this paper to the memory of a colleague and friend.

Edited by: A. Baklanov 


\section{References}

Andreae, M. O. and Rosenfeld, D.: Aerosol-cloudprecipitation interactions. Part 1. The nature and sources of cloud-active aerosols, Earth-Sci. Rev., 89, 13-41, doi:10.1016/j.earscirev.2008.03.001, 2008.

Anttila, T.: Sensitivity of cloud droplet formation to the numerical treatment of the particle mixing state, J. Geophys. Res., 115, D21205, doi:10.1029/2010JD013995, 2010.

Baklanov, A., Lawrence, M., Pandis, S., Mahura, A., Finardi, S., Moussiopoulos, N., Beekmann, M., Laj, P., Gomes, L., Jaffrezo, J.-L., Borbon, A., Coll, I., Gros, V., Sciare, J., Kukkonen, J., Galmarini, S., Giorgi, F., Grimmond, S., Esau, I., Stohl, A., Denby, B., Wagner, T., Butler, T., Baltensperger, U., Builtjes, P., van den Hout, D., van der Gon, H. D., Collins, B., Schluenzen, H., Kulmala, M., Zilitinkevich, S., Sokhi, R., Friedrich, R., Theloke, J., Kummer, U., Jalkinen, L., Halenka, T., Wiedensholer, A., Pyle, J., and Rossow, W. B.: MEGAPOLI: concept of multi-scale modelling of megacity impact on air quality and climate, Adv. Sci. Res., 4, 115-120, doi:10.5194/asr-4115-2010, 2010.

Baltensperger, U., Streit, N., Weingartner, E., Nyeki, S., Prévôt, A. S. H., Van Dingenen, R., Virkkula, A., Putaud, J.-P., Even, A., ten Brink, H., Blatter, A., Neftel, A., and Gäggeler, H. W.: Urban and rural aerosol characterization of summer smog events during the PIPAPO field campaign in Milan, Italy, J. Geophys. Res., 107, 8193, doi:10.1029/2001JD001292, 2002.

Baron, P. and Willeke, K.: Aerosol Measurement Principles, Techniques and Applications, John Wiley and Sons, 2nd edition, 2001.

Beekmann, M., Prévôt, A. S. H., Drewnick, F., Sciare, J., Pandis, S. N., van der Gon, H. A. C. D., Crippa, M., Freutel, F., Poulain, L., Ghersi, V., Rodriguez, E., Beirle, S., Zotter, P., von der WeidenReinmüller, S.-L., Bressi, M., Fountoukis, C., Petetin, H., Szidat, S., Schneider, J., Rossi, A., Haddad, I. E., Megaritis, A., Zhang, Q. J., Slowik, J. G., Moukthar, S., Kolmonen, P., Stohl, A., Eckhardt, S., Borbon, A., Gros, V., Marchand, N., Jaffrezo, J. L., Schwarzenboeck, A., Colomb, A., Wiedensohler, A., Borrmann, S., Lawrence, M., Baklanov, A., and Baltensperger, U.: Air pollution in a European megacity: the origin of fine particulate matter, submitted to Geophys. Res. Lett., 2013.

Bertram, A. K., Martin, S. T., Hanna, S. J., Smith, M. L., Bodsworth, A., Chen, Q., Kuwata, M., Liu, A., You, Y., and Zorn, S. R.: Predicting the relative humidities of liquid-liquid phase separation, efflorescence, and deliquescence of mixed particles of ammonium sulfate, organic material, and water using the organic-to-sulfate mass ratio of the particle and the oxygen-tocarbon elemental ratio of the organic component, Atmos. Chem. Phys., 11, 10995-11006, doi:10.5194/acp-11-10995-2011, 2011.

Cozic, J., Verheggen, B., Mertes, S., Connolly, P., Bower, K., Petzold, A., Baltensperger, U., and Weingartner, E.: Scavenging of black carbon in mixed phase clouds at the high alpine site Jungfraujoch, Atmos. Chem. Phys., 7, 1797-1807, doi:10.5194/acp-7-1797-2007, 2007.

Crippa, M., DeCarlo, P. F., Slowik, J. G., Mohr, C., Heringa, M. F., Chirico, R., Poulain, L., Freutel, F., Sciare, J., Cozic, J., Di Marco, C. F., Elsasser, M., Nicolas, J. B., Marchand, N., Abidi, E., Wiedensohler, A., Drewnick, F., Schneider, J., Borrmann, S., Nemitz, E., Zimmermann, R., Jaffrezo, J.-L., Prévôt, A. S. H., and Baltensperger, U.: Wintertime aerosol chemical compo- sition and source apportionment of the organic fraction in the metropolitan area of Paris, Atmos. Chem. Phys., 13, 961-981, doi:10.5194/acp-13-961-2013, 2013.

Cubison, M. J., Ervens, B., Feingold, G., Docherty, K. S., Ulbrich, I. M., Shields, L., Prather, K., Hering, S., and Jimenez, J. L.: The influence of chemical composition and mixing state of Los Angeles urban aerosol on CCN number and cloud properties, Atmos. Chem. Phys., 8, 5649-5667, doi:10.5194/acp8-5649-2008, 2008.

Ervens, B., Cubison, M., Andrews, E., Feingold, G., Ogren, J. A., Jimenez, J. L., DeCarlo, P., and Nenes, A.: Prediction of cloud condensation nucleus number concentration using measurements of aerosol size distributions and composition and light scattering enhancement due to humidity, J. Geophys. Res., 112, D10S32, doi:10.1029/2006JD007426, 2007.

Ervens, B., Cubison, M. J., Andrews, E., Feingold, G., Ogren, J. A., Jimenez, J. L., Quinn, P. K., Bates, T. S., Wang, J., Zhang, Q., Coe, H., Flynn, M., and Allan, J. D.: CCN predictions using simplified assumptions of organic aerosol composition and mixing state: a synthesis from six different locations, Atmos. Chem. Phys., 10, 4795-4807, doi:10.5194/acp-10-4795-2010, 2010.

Fors, E. O., Swietlicki, E., Svenningsson, B., Kristensson, A., Frank, G. P., and Sporre, M.: Hygroscopic properties of the ambient aerosol in southern Sweden - a two year study, Atmos. Chem. Phys., 11, 8343-8361, doi:10.5194/acp-11-8343-2011, 2011.

Frosch, M., Zardini, A. A., Platt, S. M., Müller, L., Reinnig, M.C., Hoffmann, T., and Bilde, M.: Thermodynamic properties and cloud droplet activation of a series of oxo-acids, Atmos. Chem. Phys., 10, 5873-5890, doi:10.5194/acp-10-5873-2010, 2010.

Gasparini, R., Collins, D. R., Andrews, E., Sheridan, P. J., Ogren, J. A., and Hudson, J. G.: Coupling aerosol size distributions and size-resolved hygroscopicity to predict humidity-dependent optical properties and cloud condensation nuclei spectra, J. Geophys. Res., 111, D05S13, doi:10.1029/2005JD006092, 2006.

Gunthe, S. S., King, S. M., Rose, D., Chen, Q., Roldin, P., Farmer, D. K., Jimenez, J. L., Artaxo, P., Andreae, M. O., Martin, S. T., and Pöschl, U.: Cloud condensation nuclei in pristine tropical rainforest air of Amazonia: size-resolved measurements and modeling of atmospheric aerosol composition and CCN activity, Atmos. Chem. Phys., 9, 7551-7575, doi:10.5194/acp-97551-2009, 2009.

Gunthe, S. S., Rose, D., Su, H., Garland, R. M., Achtert, P., Nowak, A., Wiedensohler, A., Kuwata, M., Takegawa, N., Kondo, Y., Hu, M., Shao, M., Zhu, T., Andreae, M. O., and Pöschl, U.: Cloud condensation nuclei (CCN) from fresh and aged air pollution in the megacity region of Beijing, Atmos. Chem. Phys., 11, 11023-11039, doi:10.5194/acp-1111023-2011, 2011.

Gysel, M., Weingartner, E., and Baltensperger, U.: Hygroscopicity of aerosol particles at low temperatures. 2 . Theoretical and experimental hygroscopic properties of laboratory generated aerosols, Environ. Sci. Technol., 36, 63-68, doi:10.1021/es010055g, 2002.

Gysel, M., Crosier, J., Topping, D. O., Whitehead, J. D., Bower, K. N., Cubison, M. J., Williams, P. I., Flynn, M. J., McFiggans, G. B., and Coe, H.: Closure study between chemical composition and hygroscopic growth of aerosol particles during TORCH2, Atmos. Chem. Phys., 7, 6131-6144, doi:10.5194/acp-7-61312007, 2007. 
Gysel, M., McFiggans, G. B., and Coe, H.: Inversion of tandem differential mobility analyser (TDMA) measurements, J. Aerosol Sci., 40, 134-151, doi:10.1016/j.jaerosci.2008.07.013, 2009.

Haeffelin, M., Barthès, L., Bock, O., Boitel, C., Bony, S., Bouniol, D., Chepfer, H., Chiriaco, M., Cuesta, J., Delanoë, J., Drobinski, P., Dufresne, J.-L., Flamant, C., Grall, M., Hodzic, A., Hourdin, F., Lapouge, F., Lemaître, Y., Mathieu, A., Morille, Y., Naud, C., Noël, V., O'Hirok, W., Pelon, J., Pietras, C., Protat, A., Romand, B., Scialom, G., and Vautard, R.: SIRTA, a ground-based atmospheric observatory for cloud and aerosol research, Ann. Geophys., 23, 253-275, doi:10.5194/angeo-23-253-2005, 2005.

Hegg, D. A.: Impact of gas-phase $\mathrm{HNO}_{3}$ and $\mathrm{NH}_{3}$ on microphysical processes in atmospheric clouds, Geophys. Res. Lett., 27, 22012204, doi:10.1029/1999GL011252, 2000.

Herich, H., Tritscher, T., Wiacek, A., Gysel, M., Weingartner, E., Lohmann, U., Baltensperger, U., and Cziczo, D. J.: Water uptake of clay and desert dust aerosol particles at sub- and supersaturated water vapor conditions, Phys. Chem. Chem. Phys., 11, 7804-7809, doi:10.1039/B901585J, 2009.

Hitzenberger, R., Giebl, H., Petzold, A., Gysel, M., Nyeki, S., Weingartner, E., Baltensperger, U., and Wilson, C. W.: Properties of jet engine combustion particles during the PartEmis experiment. Hygroscopic growth at supersaturated conditions, Geophys. Res. Lett., 30, 1779, doi:10.1029/2003GL017294, 2003.

Irwin, M., Robinson, N., Allan, J. D., Coe, H., and McFiggans, G.: Size-resolved aerosol water uptake and cloud condensation nuclei measurements as measured above a Southeast Asian rainforest during OP3, Atmos. Chem. Phys., 11, 11157-11174, doi:10.5194/acp-11-11157-2011, 2011.

Jurányi, Z., Gysel, M., Duplissy, J., Weingartner, E., Tritscher, T., Dommen, J., Henning, S., Ziese, M., Kiselev, A., Stratmann, F., George, I., and Baltensperger, U.: Influence of gas-to-particle partitioning on the hygroscopic and droplet activation behaviour of $\alpha$-pinene secondary organic aerosol, Phys. Chem. Chem. Phys., 11, 8091-8097, doi:10.1039/B904162A, 2009.

Jurányi, Z., Gysel, M., Weingartner, E., DeCarlo, P. F., Kammermann, L., and Baltensperger, U.: Measured and modelled cloud condensation nuclei number concentration at the high alpine site Jungfraujoch, Atmos. Chem. Phys., 10, 7891-7906, doi:10.5194/acp-10-7891-2010, 2010.

Kammermann, L., Gysel, M., Weingartner, E., and Baltensperger, U.: 13-month climatology of the aerosol hygroscopicity at the free tropospheric site Jungfraujoch ( $3580 \mathrm{~m}$ a.s.1.), Atmos. Chem. Phys., 10, 10717-10732, doi:10.5194/acp-10-107172010, 2010.

Kammermann, L., Gysel, M., Weingartner, E., Herich, H., Cziczo, D. J., Holst, T., Svenningsson, B., Arneth, A., and Baltensperger, U.: Subarctic atmospheric aerosol composition: 3. Measured and modeled properties of cloud condensation nuclei, J. Geophys. Res., 115, D04202, doi:10.1029/2009JD012447, 2010b.

Knutson, E. and Whitby K.: Anomalous unipolar diffusion charging of polystyrene latex aerosols, J. Colloid Interf. Sci., 53, 493-495, 1975.

Koehler, K. A., Kreidenweis, S. M., DeMott, P. J., Petters, M. D., Prenni, A. J., and Carrico, C. M.: Hygroscopicity and cloud droplet activation of mineral dust aerosol. Geophys. Res. Lett., 36, L08805, doi:10.1029/2009GL037348, 2009.

Köhler, H.: The nucleus in and the growth of hygroscopic droplets, Trans. Faraday Soc., 32, 1152-1161, 1936.
Kuwata, M., Kondo, Y., and Takegawa, N.: Critical condensed mass for activation of black carbon as cloud condensation nuclei in Tokyo, J. Geophys. Res., 114, D20202, doi:10.1029/2009JD012086, 2009.

Laborde, M., Crippa, M., Tritscher, T., Jurányi, Z., Decarlo, P. F., Temime-Roussel, B., Marchand, N., Eckhardt, S., Stohl, A., Baltensperger, U., Prévôt, A. S. H., Weingartner, E., and Gysel, M.: Black carbon physical properties and mixing state in the European megacity Paris, Atmos. Chem. Phys., 13, 5831-5856, doi:10.5194/acp-13-5831-2013, 2013.

Lance, S., Nenes, A., Mazzoleni, C., Dubey, M. K., Gates, H., Varutbangkul, V., Rissman, T. A., Murphy, S. M., Sorooshian, A., Flagan, R. C., Seinfeld, J. H., Feingold, G., and Jonsson, H. H.: Cloud condensation nuclei activity, closure, and droplet growth kinetics of Houston aerosol during the Gulf of Mexico Atmospheric Composition and Climate Study (GoMACCS), J. Geophys. Res., 114, D00F15, doi:10.1029/2008JD011699, 2009.

Liu, P. F., Zhao, C. S., Göbel, T., Hallbauer, E., Nowak, A., Ran, L., Xu, W. Y., Deng, Z. Z., Ma, N., Mildenberger, K., Henning, S., Stratmann, F., and Wiedensohler, A.: Hygroscopic properties of aerosol particles at high relative humidity and their diurnal variations in the North China Plain, Atmos. Chem. Phys., 11, 34793494, doi:10.5194/acp-11-3479-2011, 2011.

McFiggans, G., Artaxo, P., Baltensperger, U., Coe, H., Facchini, M. C., Feingold, G., Fuzzi, S., Gysel, M., Laaksonen, A., Lohmann, U., Mentel, T. F., Murphy, D. M., O’Dowd, C. D., Snider, J. R., and Weingartner, E.: The effect of physical and chemical aerosol properties on warm cloud droplet activation, Atmos. Chem. Phys., 6, 2593-2649, doi:10.5194/acp-6-25932006, 2006.

McMeeking, G. R., Good, N., Petters, M. D., McFiggans, G., and Coe, H.: Influences on the fraction of hydrophobic and hydrophilic black carbon in the atmosphere, Atmos. Chem. Phys., 11, 5099-5112, doi:10.5194/acp-11-5099-2011, 2011.

Mochida, M., Miyakawa, T., Takegawa, N., Kawamura, K., and Kondo, Y.: Relationship between hygroscopicity and cloud condensation nuclei activity for urban aerosols in Tokyo, J. Geophys. Res., 111, D23204, doi:10.1029/2005JD006980, 2006.

Moore, R. H., Nenes, A., and Medina, J.: Scanning mobility CCN analysis - a method for fast measurements of size-resolved CCN distributions and activation kinetics, Aerosol Sci. Technol., 44, 861-871, 2010.

Padró, L. T., Asa-Awuku, A., Morrison, R., and Nenes, A.: Inferring thermodynamic properties from $\mathrm{CCN}$ activation experiments: single-component and binary aerosols, Atmos. Chem. Phys., 7, 5263-5274, doi:10.5194/acp-7-5263-2007, 2007.

Petters, M. D. and Kreidenweis, S. M.: A single parameter representation of hygroscopic growth and cloud condensation nucleus activity, Atmos. Chem. Phys., 7, 1961-1971, doi:10.5194/acp-71961-2007, 2007.

Petters, M. D., Carrico, C. M., Kreidenweis, S. M., Prenni, A. J., DeMott, P. J., Collett, J. L., and Moosmüller, H.: Cloud condensation nucleation activity of biomass burning aerosol, J. Geophys. Res., 114, D22205, doi:10.1029/2009JD012353, 2009.

Pringle, K. J., Tost, H., Pozzer, A., Pöschl, U., and Lelieveld, J.: Global distribution of the effective aerosol hygroscopicity parameter for $\mathrm{CCN}$ activation, Atmos. Chem. Phys., 10, 52415255, doi:10.5194/acp-10-5241-2010, 2010. 
Rissler, J., Swietlicki, E., Zhou, J., Roberts, G., Andreae, M. O., Gatti, L. V., and Artaxo, P.: Physical properties of the submicrometer aerosol over the Amazon rain forest during the wetto-dry season transition - comparison of modeled and measured CCN concentrations, Atmos. Chem. Phys., 4, 2119-2143, doi:10.5194/acp-4-2119-2004, 2004.

Roberts, G. C. and Nenes, A.: A continuous-flow streamwise thermal-gradient $\mathrm{CCN}$ chamber for atmospheric measurements, Aerosol Sci. Technol., 39, 206-221, doi:10.1080/027868290913988, 2005.

Rose, D., Nowak, A., Achtert, P., Wiedensohler, A., Hu, M., Shao, M., Zhang, Y., Andreae, M. O., and Pöschl, U.: Cloud condensation nuclei in polluted air and biomass burning smoke near the mega-city Guangzhou, China - Part 1: Size-resolved measurements and implications for the modeling of aerosol particle hygroscopicity and CCN activity, Atmos. Chem. Phys., 10, 3365-3383, doi:10.5194/acp-10-3365-2010, 2010.

Snider, J. R., Guibert, S., Brenguier, J.-L., and Putaud, J.-P.: Aerosol activation in marine stratocumulus clouds: 2. Köhler and parcel theory closure studies, J. Geophys. Res., 108, 8629, doi:10.1029/2002JD002692, 2003.

Sorjamaa, R., Svenningsson, B., Raatikainen, T., Henning, S., Bilde, M., and Laaksonen, A.: The role of surfactants in Köhler theory reconsidered, Atmos. Chem. Phys., 4, 2107-2117, doi:10.5194/acp-4-2107-2004, 2004.

Su, H., Rose, D., Cheng, Y. F., Gunthe, S. S., Massling, A., Stock, M., Wiedensohler, A., Andreae, M. O., and Pöschl, U.: Hygroscopicity distribution concept for measurement data analysis and modeling of aerosol particle mixing state with regard to hygroscopic growth and CCN activation, Atmos. Chem. Phys., 10, 7489-7503, doi:10.5194/acp-10-7489-2010, 2010.

Swietlicki, E., Hansson, H. C., Hameri, K., Svenningsson, B., Massling, A., McFiggans, G., McMurry, P. H., Petaja, T., Tunved, P., Gysel, M., Topping, D., Weingartner, E., Baltensperger, U., Rissler, J., Wiedensohler, A. and Kulmala, M.: Hygroscopic properties of submicrometer atmospheric aerosol particles measured with H-TDMA instruments in various environments - a review, Tellus B, 60, 432-469, doi:10.1111/j.16000889.2008.00350.x, 2008.

Topping, D. O., McFiggans, G. B., and Coe, H.: A curved multicomponent aerosol hygroscopicity model framework: Part 1 - Inorganic compounds, Atmos. Chem. Phys., 5, 1205-1222, doi:10.5194/acp-5-1205-2005, 2005.

Tritscher, T.: Hygroscopicity and volatility of fresh and processed aerosols from different sources, Ph.D. thesis Nr. 19799, Federal Institute of Technology, ETH, Zürich, Switzerland, doi:10.3929/ethz-a-006705970, 2011.

Tritscher, T., Jurányi, Z., Martin, M., Chirico, R., Gysel, M., Heringa, M. F., DeCarlo, P. F., Sierau, B., Prévôt, A. S. H., Weingartner, E., and Baltensperger, U.: Changes of hygroscopicity and morphology during ageing of diesel soot, Environ. Res. Lett., 6, 034026, doi:10.1088/1748-9326/6/3/034026, $2011 \mathrm{a}$.
Tritscher, T., Dommen, J., DeCarlo, P. F., Gysel, M., Barmet, P. B., Praplan, A. P., Weingartner, E., Prévôt, A. S. H., Riipinen, I., Donahue, N. M., and Baltensperger, U.: Volatility and hygroscopicity of aging secondary organic aerosol in a smog chamber, Atmos. Chem. Phys., 11, 11477-11496, doi:10.5194/acp-1111477-2011, 2011b.

Vestin, A., Rissler, J., Swietlicki, E., Frank, G. P., and Andreae, M. O.: Cloud-nucleating properties of the Amazonian biomass burning aerosol: Cloud condensation nuclei measurements and modeling, J. Geophys. Res., 112, D14201, doi:10.1029/2006JD008104, 2007.

Wiedensohler, A.: An approximation of the bipolar charge distribution for particles in the submicron size range, J. Aerosol Sci., 19, 387-389, 1988.

Wiedensohler, A., Birmili, W., Nowak, A., Sonntag, A., Weinhold, K., Merkel, M., Wehner, B., Tuch, T., Pfeifer, S., Fiebig, M., Fjäraa, A. M., Asmi, E., Sellegri, K., Depuy, R., Venzac, H., Villani, P., Laj, P., Aalto, P., Ogren, J. A., Swietlicki, E., Williams, P., Roldin, P., Quincey, P., Hüglin, C., FierzSchmidhauser, R., Gysel, M., Weingartner, E., Riccobono, F., Santos, S., Grüning, C., Faloon, K., Beddows, D., Harrison, R., Monahan, C., Jennings, S. G., O’Dowd, C. D., Marinoni, A., Horn, H.-G., Keck, L., Jiang, J., Scheckman, J., McMurry, P. H., Deng, Z., Zhao, C. S., Moerman, M., Henzing, B., de Leeuw, G., Löschau, G., and Bastian, S.: Mobility particle size spectrometers: harmonization of technical standards and data structure to facilitate high quality long-term observations of atmospheric particle number size distributions, Atmos. Meas. Tech., 5, 657-685, doi:10.5194/amt-5-657-2012, 2012.

Zhang, R., Khalizov, A. F., Pagels, J., Zhang, D., Xue, H., and McMurry, P. H.: Variability in morphology, hygroscopicity, and optical properties of soot aerosols during atmospheric processing, P. Natl. Acad. Sci. USA, 105, 10291-10296, 2008.

Zhang, Q., Jimenez, J. L., Canagaratna, M. R., Allan, J. D., Coe, H., Ulbrich, I., Alfarra, M. R., Takami, A., Middlebrook, A. M., Sun, Y. L., Dzepina, K., Dunlea, E., Docherty, K., DeCarlo, P. F., Salcedo, D., Onasch, T., Jayne, J. T., Miyoshi, T., Shimono, A., Hatakeyama, S., Takegawa, N., Kondo, Y., Schneider, J., Drewnick, F., Borrmann, S., Weimer, S., Demerjian, K., Williams, P., Bower, K., Bahreini, R., Cottrell, L., Griffin, R. J., Rautiainen, J., Sun, J. Y., Zhang, Y. M., and Worsnop, D. R.: Ubiquity and dominance of oxygenated species in organic aerosols in anthropogenically-influenced Northern Hemisphere midlatitudes, Geophys. Res. Lett., 34, L13801, doi:10.1029/2007GL029979, 2007. 